\title{
Technological Imitation and Innovation in New European Union Markets
}

\author{
Ainura Uzagalieva \\ Evžen Kočenda \\ Antonio Menezes
}

CESIFO WORKING PAPER NO. 3039

CATEGORY 8: TRAdE POLICY

APRIL 2010

\footnotetext{
An electronic version of the paper may be downloaded

- from the SSRN website: Www.SSRN.com

- from the RePEc website: $\quad$ www.RePEc.org

- from the CESifo website: www.CESifo-group.org/wp
} 


\title{
Technological Imitation and Innovation in New European Union Markets
}

\begin{abstract}
We analyze the role of imitation and innovation in promoting technological progress in new members of European Union: the Czech Republic, Hungary, Poland and Slovakia. The two modes of technological development - innovation and imitation - are distinguished from one another by identifying the dominant orientation of innovation efforts at the industry level. Specific industry features and the origin, structure and size of foreign direct investments in these countries are utilized for this purpose. The empirical relationship between intraindustrial bilateral trade flows, which proxy the level of technological progress, and innovation expenditures is analyzed using a gravity model. During the estimation stage, we use appropriate instruments to account for the potential endogeneity of innovation to trade. The results reveal the important role of foreign direct investment and multinationals in the technological progress of the region. Specifically, technological progress that is due to innovation is driven mainly by affiliates of foreign firms and multinationals.
\end{abstract}

JEL-Code: C51, F14, F21, O31.

Keywords: foreign direct investment, innovation, imitation, international trade, European Union.

Ainura Uzagalieva
University of the Azores
S. Miguel Azores
Portugal
uzagali@uac.pt

\author{
Antonio Menezes \\ University of the Azores \\ S. Miguel Azores \\ Portugal \\ menezesa@uac.pt
}

\author{
Evžen Kočenda \\ CERGE-EI \\ Charles University \\ Czech Republic - Prague \\ evzen.kocenda@cerge-ei.cz
}

We are grateful for helpful suggestions to Lubor Lacina, Mathilde Maurel, Patrick Sevestre, Martin Srholec and Bart Verspagen. We also acknowledge comments from participants at the MICRO-DYN workshop (Cambridge) and the Mendel University seminar (Brno). While preparing this paper, Uzagalieva benefited from the EU 6th framework project MICRO-DYN and Kočenda benefited from the GACR grant No. 402/091595. The usual disclaimer applies. 


\section{Introduction}

In making regional and national policies early in the 1990s, Central European countries recognized western-style market strategies and techniques as important channels for promoting economic transformation and growth (Demekas et al. 2007; Lansbury et al. 1996; Landesmann and Stehrer 2006). Wide-ranging policies on economic reforms along with the privatizing of state-owned enterprises helped to establish private companies and bring foreign competition, foreign capital and advanced corporate-governance practices to the region (Estrin et al. 2009; Moudatsou 2003; Roland 2001; Landesmann and Dobrinsky1995; Lefilleur and Maurel 2010). These policies promoted gradual economic growth and determined a basis for innovative behavior in local firms and industries (Welfens 1999). With accession to the European Union (EU) in 2004, the policy priorities in new EU members have been increasingly devoted to research and development (R\&D) and innovation as the key drivers of productivity growth. ${ }^{1}$ This raises the important question of whether and how the modes of technological developmentimitation and innovation - relate to overall progress and competitiveness. In this paper we contribute to the literature by analyzing imitation and innovation in Central Europe, a region that recently underwent an unprecedented economic transformation. We show that the technological progress that is due to innovation is driven mainly by affiliates of foreign firms and multinationals.

Imitation and innovation were investigated as modes of technological development in many instances (e.g. Bottazzi and Peri 2003; Jaffe and Trajtenberg 2002). Theoretical studies within the framework of technology diffusion and international technology transfer (e.g. Currie at al. 1999; Jones and Williams 2000; Perez-Sebastian 2007) emphasize the importance of imitation at the earlier stages of economic convergence, while innovation dominates at later stages. By learning through the imitation of foreign ideas and techniques, ${ }^{2}$ less developed countries promote technological change to help them catch up to developed countries. This is evidently true in a globalized world economy with a rapid integration of economic processes and an increasing number of converging clubs, including the EU (Grossman and Helpman 1991). Because of the effect of the economic transformation of Central European countries, there is a lack of research on this phenomenon for economies that have recently joined the EU. Firstly, learning through imitation itself is relatively new in these countries where markets have just been established. Secondly, an adequate data set on innovation at a reasonable level of disaggregation and quality is still not available for many of these countries. Consequently, issues associated with the lack of data and, thus, adequate tools cause difficulties in analyzing the issue properly. Finally, a common innovation measure that is based on either R\&D or patents has been criticized for unrealistic underlying assumptions for analyzing innovation. ${ }^{3}$

The purpose of this paper is to analyze the role of imitation and innovation in the technological development in four new EU members: the Czech Republic, Hungary, Poland and Slovakia. In

\footnotetext{
${ }^{1}$ The EU Lisbon strategy of 2005 stresses that "knowledge transfer via researcher mobility, foreign direct investments (FDI) and imported technology is of particular importance for lagging countries and regions" (http://ue.eu.int/ueDocs/cms_Data/docs/pressData/en/ec/84335.pdf).

${ }^{2}$ For example, Japanese firms made huge progress from borrowing, modifying and successfully commercializing foreign technologies and ideas during the post-war period (Okimoto and Saxonhouse 1987).

${ }^{3}$ The assumption of perfectly rational behavior of firms is seen to be unrealistic for analyzing innovation processes.
} 
order to distinguish innovation from imitation, we identify the dominant orientation of innovative efforts at the industry level, using R\&D expenditures as a measure of innovative effort. Following Baysinger and Hoskisson (1989), Griliches (1998) and Hagedoorn and Cloodt (2003), we expect that particularly in high-tech industries, the impact of innovative (or R\&D) efforts on the technological and innovative performance of firms is especially strong. The innovative performance of firms is defined in the broadest possible sense in this study, following Ernst (2001) and Freeman and Soete (1997). That is, it refers to all innovation stages, including the birth of a new idea resulting from R\&D activities, the introduction of new inventions (patenting), and the marketing of new products (Ernst 2001). Hence, our approach focuses on specific industries only, often referred to as leading-edge and high-tech-level Schumpeterian manufacturing sectors. We assume that innovative efforts undertaken by companies in these industries are a very important part of their technological performance in generating new ideas, a large part of which eventually leads to new patents and products.

The progress effect of innovation effort is analyzed further with a gravity model, which is based on the assumption that technology diffusion mirrors the geographical pattern of trade (Eaton and Kortum 2002; Grossman and Helpman 1991; Leamer and Levinsohn 1995; Rivera-Batiz and Romer 1991). In the gravity model, intra-industrial bilateral trade flows are taken as an approximate measure of technological progress. The basic intuition behind this model is that the larger the volume of intra-industrial trade between two countries, the higher the probability that innovators in the country with less technological knowledge converges to the country with more technological knowledge, as argued by Grupp (1998). The choice of intra-industrial bilateral flows is justified by the fact that they give rise to trade within similar commodity markets between the countries as stressed in Grubel and Lloyd (1975) and Greenaway and Milner (1986). The potential endogeneity of innovation with respect to trade in the dynamic panels is treated with instruments obtained from the Community Innovation Survey (CIS). ${ }^{4}$ The data used in this study, consequently, cover CIS- and non-CIS-based innovation indicators for two groups of countries, including four new and 16 old EU members for the period from 1995 to $2006 .{ }^{5}$ The sources of the data are the Main Science and Technology Indicators (MSTI) of the Organization for Economic Cooperation and Development (OECD) of the United Nations Industrial Development Organization (UNIDO) and Eurostat databases.

This study contributes to the literature by focusing (apart from the innovation indicators) on the origins and direction of FDI and its role in the technological progress of the selected new EU members. FDI is an important means of technological and knowledge transfer. The case of the new EU countries is of particular interest since they received a substantial amount of FDI during the transformation period (Carstensen and Toubal 2004; Disdier and Mayer 2004). ${ }^{6}$ The results reveal the important role of FDI and multinationals in the technological progress of the region and complement the recent results of Lefilleur and Maurel (2010) that show the key role of FDI in integrating Central European (CE) countries into the European production process. In

\footnotetext{
${ }^{4}$ The CIS is a survey on innovation activity in enterprises, covering EU Member States, EU Candidate Countries, Iceland and Norway.

${ }^{5}$ The group of old EU members includes: Austria, Belgium, Denmark, Finland, France, Germany, Greece, Iceland, Ireland, Italy, Luxemburg, the Netherlands, Portugal, Spain, Sweden, and the UK.

${ }^{6}$ During the period from 1990 to 2007, the four new EU members received $\$ 271.6$ bln. FDI in total. The breakdown for each country is as follows: the Czech Republic ( $\$ 69.9$ bln.), Hungary ( $\$ 62.5$ bln.), Poland ( $\$ 114.1$ bln.), Slovakia (\$25.2 bln.). For more details see OECD Statistics: 2008.
} 
particular, we show that technological progress that is due to innovation is driven chiefly by affiliates of foreign firms and multinationals. Our results are in line with the experience of countries in other regions of the world, like the US and China. Nowadays, China is the largest recipient of foreign capital among developing countries, particularly receiving money from the US ${ }^{7}$. As a percentage of the gross inflow of capital coming from abroad, the total size of FDI in China increased from $6 \%$ to about $70 \%$ during $1980-2000$ (Fung et al. 2004). ${ }^{8}$ The direct technology transfers from multinational corporations to local subsidiaries played a very important role in advancing technologies as well as promoting rapid economic growth in China (Yao and Wei 2007). The rest of the paper is organized as follows. Section 2 presents the theoretical and empirical background. Section 3 describes the gravity model of bilateral trade. Section 4 reviews the innovation and trade flows measures. The empirical model specification and data are presented in Section 5. The conclusion follows.

\section{Theoretical and empirical background}

Imitation and innovation are important modes of technological development. Their nature, characteristics, interdependence and/or evolution over time are frequently discussed in the economic literature, usually focusing on a single country (Barro and Sala-i-Martin 1997; Bottazzi and Peri 2003; Glass and Saggi 1998; Grossman and Helpman 1991; Jaffe and Trajtenberg 2002; Jones 1995; Segerstrom 1991). In the endogenous growth literature (Barro and Sala-i-Martin 1997, Glass and Saggi 1998 and Grossman and Helpman 1991), imitation and innovation cannot coexist within a single country. Namely, North-South models with technology transfer between rich and poor regions distinguish the South as a region of countries that are either not innovators or are only innovators after being imitators initially. Many researchers have argued, however, that an equilibrium with both imitation and innovation within a single country can exist (e.g. Currie et al. 1999; Jones and Williams 2000; Segerstrom 1991).

According to Segerstrom (1991), the prospect of collusion between firms provides incentives to engage in costly imitation. Models with catching-up features, in which equilibrium with imitation and innovation within specific countries depends on a cross-country assimilation effect and the ease of imitation, are provided in Currie et al. (1999). The reasons and factors for R\&D over- and underinvestment as well as the conditions under which an optimal allocation of imitation and innovation can co-exist were explored further by Jones and Williams (2000) and Segerstrom (2000, 2004). Perez-Sebastian (2007) incorporated into these models transitional dynamics along the development path and arrived at the conclusion that imitation possibilities change over time. To be more specific, the policy intensity of imitation decreases as initially poor countries develop and integrate with more advanced ones. As a consequence, the early stages of convergence are characterized by a high intensity of imitation activities, while in later stages innovation dominates.

\footnotetext{
${ }^{7}$ The US is the second largest investor with about 9\% in total FDI after Hong-Kong (48\%).

${ }^{8}$ The number of foreign-invested enterprises in China increased by $11 \%$ between 1995 and 2000, including half of the total number of firms operating in the electronics and telecommunication industry, for example (Fung et al. 2004).
} 
The economic reasons for the high intensity of imitation are covered in Poyago-Theotoky (1998). In particular, under weak patent protection and strong technological spillovers, private firms underfund $R \& D$ and innovative activities. Then, they reap the benefits of innovation through easy imitation once a new invention has been made. Thus a free-rider aspect of R\&D can cause an underinvestment problem that can be corrected, initially, by policy measures through government subsidies to $R \& D$ expenditures, $R \& D$ tax credits and cooperative ventures in $R \& D$.

New EU members constitute one group of countries where the above-mentioned processes are at the very heart of their transformation and integration development. In particular, the countries managed to replace on a large scale outdated equipment and machinery in their factories, improve their infrastructure, and adopt new technologies. They have also progressed in their integration process and economic convergence towards the EU in terms of the real economy (Kočenda 2001) as well as in terms of nominal (Kočenda et al. 2006) and fiscal (Kočenda et al. 2008) indicators.

Aside from specific issues that are relevant for these new EU members, the relationship between innovation and technological progress has been studied empirically using exogenous North-South models (e.g. Krugman 1979) and endogenous growth models (e.g. Grossman and Helpman 1990; Young 1991). According to North-South models, the North innovates and exports newly invented goods to the South. Then, the South initially imitates these goods and, as soon as it becomes mature, exports them to the rest of the world. In this respect, the North ought to continually innovate in order to keep its exports high. Different aspects of structural transformation and the competitiveness of countries are covered in Fagerberg et al. (2007), Landesmann and Stehrer (2006), using a growth model based on Schumpeterian logic. The authors emphasize technology, capacity and demand as of greater importance for growth and development than price competitiveness. Endogenous growth models recognize the open-economy effect by endogenizing innovation so that the impact of international trade on innovation can be predicted. Progress indicators depicting innovation progress that are frequently used in the empirical literature include total factor productivity variables, production indexes, technology-dependent employment and foreign trade indices.

According to Grupp (1998), any indicator that is meant to capture the progress effect of innovation should identify international markets in which the domestic economy is competitive. In this respect, foreign trade variables are traditionally considered the best progress indicators since they are closely related to the product specialization of countries as well as importsubstitution sectors within countries. Besides, they can allow a structural comparison between national economies with different sizes and geographic locations. For these reasons, empirical studies investigating cross-country variations in the pattern and magnitude of the impact caused by innovation on progress connect innovation with foreign trade indicators (e.g. Bleaney and Wakelin 2002; Buxton et al. 1991; Fagerberg 1988; Smith et al. 2002).

The competitiveness of tradable goods can also be achieved through low prices rather than high quality. Undervalued currency and exchange rate regimes that have been relaxed only around the turn of the century enabled this development in price competitiveness in several Central European countries during the early transformation period (Kočenda and Valachy 2006). With trade liberalization during the 1990s, however, many Central European countries began to experience an increase in prices as well as quality (see e.g. Morada-Gonzalez and Viaene 2005). For this reason, the present study employs deflated data, using the deflator at 2000 prices, when 
nominal exchange rates and domestic output stabilized in many of these countries. In light of the above-mentioned studies, this paper focuses on the potential effect of innovation on bilateral trade flows between country pairs drawn from a sample of 20 EU countries: four new and 16 old EU members.

There are several ways to measure innovation. Commonly used measures include R\&D inputs, patent counts and citations, new product and process announcements and survey-based measurements. Many studies use single indicators, while some studies use composite measures. The usefulness of these indicators in measuring innovation, as a single or a composite index, depends on the specific nature of the industries (Hagedoorn and Cloodt 2003). Differences in the nature of industry activities determine why certain innovation indicators are better (Brouwer and Kleinknecht 1999; Devinney 1993; Ernst 2001; Griliches 1998). The more an industry is characterized by high $\mathrm{R} \& \mathrm{D}$, high patenting intensity and/or a high ratio of new product introduction, the better the quality of the corresponding indicator. It is well known that particularly in high-tech industries, $R \& D$ expenditures, patents and new products play an important role in indicating the innovative performance of companies (OECD 1997).

The innovative performance of companies can be defined in a narrow or broad sense, according to Ernst (2001) and Freeman and Soete (1997). The narrow sense refers to innovation as a result of a company's activity in terms of the degree to which it introduces newly invented products, process or devices. Innovation occurs when a company first markets a new product or introduces a new process. This enables followers to imitate or adopt these newly invented goods and processes. According to Grupp (1998) and Pianta (2003), the distinction between innovation and imitation at this level can be made in two ways. First, a distinction can be made through examining the evolution of particular technologies by their development stages. Second, it can be made through clear identification of innovating firms and industries. Both ways of distinction require conducting detailed surveys at the firm level since the usual innovation measures (i.e. R\&D and patent indicators) do not clearly distinguish between the two modes of technological development. The main problem comes from the fact that the product and process innovations contained in the existing surveys (e.g. firm-level CIS surveys) are not necessarily new to the market and firms are not necessarily the first ones to have introduced these inventions (Eurostat 2004). In addition, since imitators do not have to know the first innovators within the industries or countries they operate in, imitation can be as resource- and R\&D-intensive as if it was the first innovation. Therefore, distinguishing innovation from imitation on the basis of the existing firmlevel CIS surveys and the MSTI data set is difficult.

A broader understanding of the concept of innovation performance assumes innovation as a chain process from the birth of a new idea - generally measured by R\&D efforts - to the introduction of a new invention through patenting and the final announcement of new products and processes (Ernst 2001). This study relies on a broader understanding of innovation, viewing the impact of innovative efforts on the technological and innovative performance of companies as especially strong in high-tech industries (Baysinger and Hoskisson 1989; Griliches 1998; Hagedoorn and Cloodt 2003). Having in mind the above-mentioned complexities in distinguishing innovation from imitation, we select specific high R\&D-intensive and science-based industries with a dominant orientation towards innovation activities. These industries are referred to as high-techlevel Schumpeterian industries and very often include the aerospace, electronic, office machinery and computer, pharmaceutical and instrument-producing branches. Hence, following the 
approach of Grupp and Maital (2000) and Hagedoorn and Cloodt (2003), we distinguish between innovation and imitation by assuming that $\mathrm{R} \& \mathrm{D}$ expenditures in high-tech industries represent the dominant orientation of innovative efforts in generating new ideas, the largest part of which leads to new inventions. ${ }^{9}$ The progress effect of innovative efforts is analyzed further with a gravity model, which is introduced in Section 3.

\section{The gravity model of bilateral trade}

In its simplest form, the gravity model of bilateral trade, which was used by Linneman (1966), relates trade between country $i$ and country $j$ to the proportion of the product of both countries' GDP $\left(Y_{i}\right.$ by $\left.Y_{j}\right)$ and the distance between them $\left(D_{i j}\right)$ as a proxy for transaction costs. Initially, gravity models lacked a strong theoretical background, but still were widely and successfully used to empirically analyze bilateral trade flows. Later studies have been increasingly showing that gravity models can have a solid theoretical foundation, such as Ricardian, Heckscher-Ohlin, and increasing-returns-to-scale (IRS) models (Anderson 1979; Bergstrand 1990; Deadorff 1984, 1998; Eaton and Kortum 2002; Helpman 1987). The key assumption behind these models is product specialization with a single commodity produced in only one country. That is, as an exporting country increases the supply of its product, the importing country will increase its consumption proportionally, which will result in larger volumes of trade between the two countries (e.g. Evenett and Keller 2002).

A more detailed theoretical and empirical explanation for the bilateral trade between countries is reflected in new trade theories (e.g. Deardorff 1984, 1998; Helpman 1981, 1987, 1998; Krugman 1979). These studies are based on an assumption of monopolistic competition and economies of scale and link empirical facts (e.g. trade between similar countries) with a basic theoretical foundation of international trade. In particular, in the presence of economies of scale, production is located in one country, where producers differentiate their product. The larger the country in terms of GDP, the wider the variety of goods is offered. Thus, product differentiation causes trade between similar countries in such a way that the more similar two countries are, the larger the volume of their bilateral trade. Consequently, the volume of trade depends largely on the size of a country in terms of GDP. The standard gravity model predicts that the trade flow between two countries is positively related to the product of their outputs and negatively related to the distance between them.

Evenett and Keller (2002) evaluate gravity equations within the framework of perfect and imperfect specialization production models. According to their findings, models with imperfect specialization are better candidates for matching trade volumes with GDP compared to perfect specialization models. This is because the former models provide more realistic predictions where the factor proportionality of trade with GDP is less than one, while the latter models overpredict the volume of trade. Moreover, in imperfect specialization models the degree of specialization is a function of relative factor abundance, a key exogenous variable. Consequently, the authors suggest that trade among the industrialized countries can be partially captured by a

\footnotetext{
${ }^{9}$ We acknowledge, however, that patenting behavior can be explained by potential imitation due to the protection of imitation by patents or technological restrictions as in, for example, the pharmaceutical, software and computer and semiconductor industries (see e.g. Bessen and Maskin 2000). Illegal imitations are still possible, though.
} 
model that combines trade in perfectly specialized, differentiated and homogeneous goods. Trade between less developed and industrialized countries can be quite well explained by imperfect specialization models. The basic theoretical assumptions for the use of gravity equations are, therefore, balanced trade between two identical countries, ${ }^{10}$ zero trade and transport costs and no trade in intermediate goods. Evenett and Keller (2002) considers first an IRS model with two countries $(i, j)$ and two goods $(x, z)$ of differentiated varieties. Since the IRS model leads to the perfect specialization of production for each variety, the flow of trade can be presented in a very simple way as the following equation:

$$
M^{i j}=\frac{Y^{i} Y^{j}}{Y^{w}}, \text { where }
$$

$M^{i j}$ is country $i$ 's imports from $j, Y^{i}$ and $Y^{j}$ is the GDP of the two countries and $Y^{w}$ denotes the GDP of the world. Therefore, imports are strictly proportional to GDP.

The gravity equation with imperfect specialization of production, which is seen as a better candidate for matching trade volumes with GDP, is a more general version of equation (1) and incorporates a broader set of assumptions. These are: two countries $(i, j)$ with capital $(k)$ and labor $(l)$ and two sectors $(x, z)$. One sector $(z)$ produces a homogeneous good under constant returns to scale, while the second sector $(x)$ produces a differentiated good under increasing returns to scale (Helpman 1981). The homogeneous good $(z)$ is more labor-intensive in production and country (i) is capital abundant. In this setup, the gravity equation is as follows:

$$
M^{i j}=\left(1-\gamma^{i}\right) \frac{Y^{i} Y^{j}}{Y^{w}}, \text { where }
$$

$\gamma^{i}$ is the share of good $z$ in country $i$ 's GDP, presented in equation 3.

$$
\gamma^{i}=\frac{z^{i}}{\left(p_{x} x^{i}+z^{i}\right)}, \text { where }
$$

$p_{x}$ is the relative price of good $x$. Country $i$ exports only capital-intensive $x$ goods and its share in GDP is equal to $\left(1-\gamma^{i}\right)$ so that the production value on which country $j$ draws for its imports is (1$\left.\gamma^{i}\right) Y^{i}$. According to the assumption of homothetic preferences, country $j$ buys good $x$ from abroad according to its share in world GDP, which is equal to $Y^{j} / Y^{w}$. Thus, for any level of $\gamma^{i}>0$, the level of bilateral imports is lower than in the case where both goods are differentiated. The higher the volume of trade, the lower the share of homogeneous goods in GDP. Imports are less than proportional to product $(z)$ and the extent of the shortfall depends on the size of the differentiated goods sector $(x)$ in GDP.

Most gravity applications include other variables in addition to the output and distance measures. Recent studies cover a wide range of economic relationships. These include, for example, the impact of natural disasters and catastrophic events (Gassebner et al. 2006) and internet connections (e.g. Freud and Weinhold 2004) on bilateral trade flows. The impact of institutions

\footnotetext{
${ }^{10}$ The two countries are identical in terms of production technology and homothetic consumer preferences.
} 
and opening of embassies in transition economies is analyzed in Koukhartchouk and Maurel (2004) and Afman and Maurel (2009). Our model is based on the assumption that technology diffusion mimics the geographical pattern of the intra-industrial trade that gives rise to trade between two countries within similar commodity markets. In particular, the larger the trade volume of similar products between two countries, the higher the probability that innovators at one end reach the technology knowledge at the other (Grupp 1998).

\section{The empirical specification of the gravity model.}

The gravity model in the current study is based on the assumption that technology diffusion mimics the geographical pattern of intra-industrial trade, which gives rise to trade within similar commodity markets between two countries. In particular, the larger the trade volume of similar products between two countries, the higher the probability that innovators in one country reach the level of technology knowledge in the other. The main question of interest is, then, how the two modes of technological development (i.e. innovation and imitation) affect bilateral trade flows at the industry level. Since most new EU countries have recently been experiencing rapid growth, one can assume that innovation activity has been increasing. This is because firms accelerate the introduction of new export products in order to remain competitive with both domestic and foreign competitors. We take into account the fact that certain types of innovation may require a longer time to effect firm performance. Therefore, both contemporaneous and lagged time frames are considered in this study, covering the years 1996, 2000, 2004 and $2006 .{ }^{11}$

We formulate the gravity model for three different dependent variables as follows:

$$
\begin{aligned}
& \log \left(T_{i j t}^{i n n o v}\right)=\alpha_{0}+\alpha_{1} \log \left(Y_{i t} / Y_{j t}\right)+\alpha_{2} \log \left(E_{i t} / E_{j t}\right)+\alpha_{3} \log \left(D_{i s t}\right)+\alpha_{4} \log \left(I_{i t-1} / I_{j t-1}\right)+\alpha_{5} D+e^{1}, \\
& \log \left(T^{i m i t}{ }_{i j t}\right)=\beta_{0}+\beta_{1} \log \left(Y_{i t} / Y_{j t}\right)+\beta_{2} \log \left(E_{i t} / E_{j t}\right)+\beta_{3} \log \left(D i s t_{i j}\right)+\beta_{4} \log \left(I_{i t-1} / I_{j t-1}\right)+\beta_{5} D+e^{2}{ }_{i t},
\end{aligned}
$$

$$
\log \left(F_{i j t}\right)=\gamma_{0}+\gamma_{1} \log \left(Y_{i t}\left(Y_{j t}\right)+\gamma_{2} \log \left(E_{i t} / E_{j t}\right)+\gamma_{3} \log \left(D_{i s t_{i j}}\right)+\gamma_{4} \log \left(I_{i t-1}\right)+\gamma_{5} \log \left(I_{j t-1}\right)+\gamma_{6} D+\right.
$$

$e^{3}$ it.

The dependent variable $T$ in equations (4.1) and (4.2) denote intra-industrial trade flows from country $i$ to country $j$ at time $t$. The main difference between equation (4.1) and equation (4.2) is that the industry grouping is included in the specification in order to distinguish innovation from imitation in the broadest possible sense. In particular, the trade flow variables in equation (4.1) include only specific, research-intensive or science-based Schumpeterian industries. ${ }^{12}$ According to Baysinger and Hoskisson (1989), Griliches (1998) and Hagedoorn and Cloodt (2003), the impact of innovative efforts on the technological and innovative performance of companies in generating new ideas, patents and products is especially strong in high-tech industries compared to other branches. Therefore, we assume that R\&D expenditure in high-tech industries represent

\footnotetext{
${ }^{11}$ The most recent Community Innovation Surveys are available for 2006.

${ }^{12} \mathrm{We}$ focus on industrial production in specific high-tech industries that are considered highly innovative compared to traditional manufacturing sectors such as food, drink, tobacco, metal, construction products, paper and textiles. Firms in these sectors are considered more heterogeneous in terms of their innovative performance. Companies in the service sector are even less innovative than those in traditional manufacturing (see e.g. Grupp and Maital 2000).
} 
the dominant orientation of innovative efforts in generating new ideas, which leads to more inventions, in terms of new patents, products and processes, than in other industries. Following this, we use the second specification, equation (4.2), which includes the remaining manufacturing industries, as a proxy for trade in imitated goods.

Nominal export values are converted into real values by using the harmonized GDP deflator of the euro zone to neutralize price differences across the countries included. The term $Y$ denotes the constant value-added and $E$ stands for the number of employees in the manufacturing sectors of the countries considered. The term Dist stands for distances (in kilometers) between the countries' capitals, and $I$ indicates innovation (or R\&D) expenditures. The term $D$ is assigned as a dummy for the new EU members, where the share of multinationals in R\&D and innovation expenditures is high. In the third specification, equation (4.3), instead of bilateral trade flows, we use the aggregate FDI flows between the pair of countries denoted by $F$, since FDI is an important means of technology transfer. The terms $i$ and $j$ denote exporting and importing countries such that $i=1, \ldots, 20, j=1, \ldots, 20$ and $t$ stands for years such as $t=1,2,3,4 .{ }^{13}$ Finally, the parameters to be estimated by the gravity model are $\alpha_{0}, \ldots, \alpha_{5}, \beta_{0}, \ldots, \beta_{5}$ and $\gamma_{0}, \ldots, \gamma_{6}$, and $e^{1,2,3}$ it as the error terms.

Since the innovation proxy is likely to be correlated with the error term due to the endogeneity of innovation to trade, the variation in innovation that is exogenous to exports needs to be identified (Bernard and Jensen 1999; Clerides at al. 1998). Hence, several methods were used for correcting for endogeneity issues, including Granger-causality tests, a time-sequence analysis of firms' performance with respect to exports and simultaneous equation systems. Lachenmaier and Woessmann (2004) note, however, that some of these methods might not be as suitable, such as, the Granger-causality concept due to its forward-looking nature. Specifically, high diffusion rates within industries do not necessitate incorporating the lagged innovation variables. They argue that innovation proxies and exogenous variation in the innovation indicators (e.g. impulses and obstacles that hinder innovation at the firm level) are more sensible in treating these issues. Therefore, following Lachenmaier and Woessmann (2004), the impulses and obstacles which impact firm innovativeness are used as an instrument for innovative activity in two-stage least squares estimation (2SLS) of equations (4.1) and (4.2).

The instruments are obtained from the CIS where economic activities are broken down by NACE division (see Table 1). The major impeding factors that firms experience under innovation activity are classified as "hampered innovation activities" in the CIS databases. These factors include excessive economic risks, high innovation costs, a lack of appropriate sources of finance and qualified personnel, organizational rigidities and a lack of customer responsiveness to new products. Since these factors are assumed to be uncorrelated with the error term, the way of identification using the instruments ensures that the innovation estimates are solely affected by the variation of innovation activities, which are exogenous to the export performance of firms. The formal test of the $\mathrm{H}_{0}$ hypothesis that instruments are correlated with error terms, based on $\mathrm{NR}^{2} \sim \chi^{2}$, is rejected in favor of valid instruments. Consequently, the estimates of the 2SLS can be interpreted as the causal effect of innovation on exports.

\footnotetext{
${ }^{13}$ By using the ratios of variables between pairs of countries we account for different degrees of openness.
} 


\section{Data and empirical results}

This section describes innovation-related indicators in the new as well as old EU members, along with empirical results. The data is obtained through the OECD and Eurostat MSTI databases and broken down by main economic activities and sources of investment at the industry level. As mentioned in the sections above, based on a broad definition of innovative performance, we assume that the dominant orientation of innovative activities and efforts takes place in specific high-tech and science-based industries. These industries include the aerospace, electronic, office machinery and computer, pharmaceutical and instrument-producing branches. The data for these industries, which are very often referred to as leading-edge and high-tech Schumpeterian industries, cover constant exports and value-added variables, the size of employment, and the CIS-based indicators. R\&D expenditures are taken as innovative efforts; factors hampering and obstacles to innovation come from the micro-aggregated CIS databases for 1996, 2000, 2004 and 2006. The FDI flows between the country pairs and the share of multinationals and FDI in innovation expenditures are taken at the aggregated level for each country for the period from 1995 to 2006.

We now present a brief descriptive overview of comparative statistics on the main innovation indicators in terms of R\&D activities (see Table 2). Clearly, there is a notable difference in the magnitude, structure and main source of finance in the R\&D expenditures of the new and old EU members. As shown in Figure 1, for example, the gross domestic expenditure on R\&D (GERD), ${ }^{14}$ measured in terms of EUR per inhabitant, are significantly lower in the new EU members. For new EU countries, the size of these R\&D expenditures as a percentage of GDP decreased in 2006 relative to 1996 by about $0.65 \%$ of GDP on average, while in the old members it increased by about $0.89 \%$.

Figure 2 demonstrates further the main sources of finance, including the four main institutional sectors: the business enterprise sector, the government sector, the higher education sector, the private non-profit sector and the foreign sector. The largest part of R\&D activities is financed by the government sector in the new members of the EU with the exception of the Czech Republic, where business enterprises have a large share (57\%); this is slightly above the average level of the old EU members (53\%). Poland and Slovakia are characterized by a very large portion of research projects supported by government funds (about 58\% and 56\%, respectively). According to Poyago-Theotoky (1998), governments overinvest while the private sectors underinvest into $R \& D$ activities when the free-rider aspect of $R \& D$ is especially strong. In particular, in the environment of imperfect patent protection and strong technological spillovers, with easy access to research results, private firms leave R\&D activities to their rivals. Then, when a new invention has been made, the private firms reap the benefits of innovation through easy imitation. Consequently, there is an important reason for governments to correct the underinvestment problem by active policy measures through R\&D subsidies, tax credits and cooperative joint ventures, which may be the case in these new EU members.

\footnotetext{
${ }^{14}$ GERD is composed of business enterprise expenditure on R\&D (BERD), higher education expenditure on R\&D, government expenditure on $R \& D$ and private non-profit expenditure on $R \& D$.
} 
The R\&D expenditures of the business sector increased greatly in the Czech Republic and Hungary over time (see Figure 3), especially between 2001 and 2006, while Poland and Slovakia show a clear declining trend. There was a large increase in the size of business R\&D expenditures financed from abroad in the new EU members. This was especially the case in Poland and Slovakia, where expenditures increased by $4.4 \%$ and $8.5 \%$, respectively. For the old members there is a declining trend during 2001-2006 (see Figure 4). ${ }^{15}$ The overall data demonstrate that the business sectors of the new members are still much less R\&D-intensive than those of the old members. Besides, a relatively large part of the R\&D activities in the new member group is financed from outside of the business sector.

Since R\&D is an important but not the only input of innovative activities, we review other indicators as well-for example, patents, the technology balance of payments (TBP) and international trade - especially for R\&D-intensive and science-based industries. Table 3 provides comparative statistics on these industries, separately for the new and old EU members. The TBP indicators characterize the commercial transactions related to international technology transfers. They show that the net amount of payments for the acquisition and use of patents, licenses and various kinds of know-how containing industrial R\&D carried abroad is generally high in the new EU member countries. On the contrary, in the old EU members, the net amount of payments is negative. The size of these payments, along with the R\&D activities financed abroad directly and indirectly (through government funds), gives a basic indication of how large the magnitude of the imported technology to the new EU member countries is.

Our estimation steps include, first, the gravity regression where the trade flows between similar (science-based, research-intensive) industries are taken as a dependent variable to account for the potential progress effect of innovation. Second, we analyze the potential progress effect of imitation using trade flows between all the remaining manufacturing industries, taken as a proxy for imitated products. Finally, the estimates of both equations are compared to the gravity regression with bilateral FDI flows.

For pretesting purposes we use ordinary least squares (OLS), fixed effect (FE) and random effect (RE) models. The model selection is based on the properties of the residuals obtained for each model. The OLS and FE models do not satisfy the requirements for residuals being independently and identically distributed. The $\mathrm{H}_{0}$ of no $\mathrm{AR}(1)$ serial correlation in OLS residuals is rejected at the 5\% level. Both the White and Housman specification tests suggest that the RE model is the preferred option. The hypothesis test is that the individual country-specific effects are uncorrelated with the other regressors in the model. The reported $\chi^{2}$ value is smaller than the critical value, so the $\mathrm{H}_{0}$ cannot be rejected at the $5 \%$ significance level. ${ }^{16}$ Therefore we opted for the RE model that yields white noise residuals.

The summary of the estimation results from the RE model is reported in Table 4 and constitutes our main estimation results. The estimates from the first model suggest that with an increase in the size of research-intensive manufacturing sectors (proxied by the ratio of value-added) the

\footnotetext{
${ }^{15}$ The data for Austria and the UK are missing in this computation.

${ }^{16}$ The results of the tests are not reported but they are available upon request. Detailed results from the estimations of the three models are reported in Table A1 in the Appendix.
} 
flow of innovative products between countries increases, as expected. An increase in the ratio of employees in these industries contributes to a decrease in trade flows, however, the estimated parameter is not significant at the usual levels. With an increase in the distance between countries, the trade and FDI flows decrease. As for the impact of innovation, the effect is positive and significant at the 5\% significance level.

The first specification explains about $25 \%$ of the variation in the bilateral trade flows. In the new EU members, the share of foreign affiliates in innovation expenditures is very high, as documented by the FDI data presented in Table 5. Multinationals appear to be the main driving force of growth, especially in the research-intensive branches of the manufacturing sector. Namely, the inward activity of multinationals is very important in the manufacturing sector of the new EU member states, with their shares in the turnover as well as R\&D expenditure being more than $50 \%$, on average. The FDI inflows to the research-incentive manufacturing sectors is also high, ranging from $60 \%$ to $70 \%$ on average during the period from 2001 to 2006 (see Table 6). Most of the R\&D-related projects in the region are initiated and performed by multinationals. All in all, indicators presented in the above-mentioned tables suggest that the dominant orientation toward innovation efforts is concentrated mostly in the foreign firms' affiliates in the region. In this respect, in the new EU countries, bilateral trade in research-intensive or innovative products between similar industries decreases by about 3.64 times (the exponent of the coefficient on the dummy variable [1.29] on new EU members countries).

With respect to the potential role of imitation in technological development, which refers to the second model specification, taken as trade flows between the remaining manufacturing industries, the coefficient of the size of research-intensive industries has a negative sign. In particular, with an increase in the ratio of value-added in the science-based industries between two countries, the flow of imitated goods decreases. Increases in the ratios of employees as well as $R \& D$ expenditures in research-intensive sectors contribute to a decrease in the trade flow of these products. The dummy variable for the new EU members in this specification is positive and significant at the $10 \%$ level. This suggests that the export of goods produced in less R\&Dintensive manufacturing industries, which is taken as a proxy for the export of imitated goods, increases by about 1.17 times (the exponent of the dummy variable is 0.16 ).

Finally, the third specification-where the aggregate FDI flows from exporting to importing countries are taken as a proxy of technological diffusion-explains $21 \%$ of the variation. The variable based on the size of research-intensive industries positively affects the flow of FDI at the $1 \%$ significance level. The number of employees in the high-tech branches has the expected sign, however, the estimated parameter is not significant. In the case of the new members, furthermore, the outflow of FDI is systematically lower by about 7.5 times, which is reasonable since these countries are receivers of FDI. Besides, there was a large inflow of funds to these countries in recent years for various kinds of technical services, assistance and consultancy work performed abroad, as indicated in the large and positive values of the TBP indicators (Table 3). Presumably, these technologies were transferred further for supporting domestic R\&D efforts concentrated mostly in the public (e.g. government and education) sectors, as demonstrated in Table 2. In contrast, the share of the new EU members in the triadic patent variables is very low relative to the average level of the old EU members, while the size of foreign co-investors in patent applications is high (Table 6). This implies a relatively low innovation capacity of local industries, as our results suggest. All in all, the results confirm the view that the progress effect of 
innovation is led by foreign-affiliated companies and multinationals in the new EU members.

\section{Conclusion}

This paper focuses on the origins and potential progress effect of innovation in a group of new EU member countries. First, we identify the sources and dominant concentration of innovative efforts to distinguish innovation-based technological growth from imitation in these countries. Then we analyze at the industry level the origins and size of FDI as well as the main sources and direction of innovation expenditures in the science-based industries of the new EU members versus the group of old members. The comparative analysis reveals that the orientation towards innovation efforts is concentrated chiefly in corporate affiliates of foreign firms in these countries. This finding is consistent with the experience of other countries, particularly the US and China. In China, the large inflows of FDI in the last two decades and the direct technology transfers from multinational corporations to local subsidiaries played a very important role in advancing technology as well as promoting rapid economic growth (Fung et al 2004).

Finally, we estimate the potential progress effects of innovation and imitation on the basis of a gravity model on the sample of 20 countries while treating endogeneity issues using CIS-based instruments. Our results reveal that an increase in the size of the science-based manufacturing industries leads to higher intra-industrial trade between the countries, which proxies innovationbased technological growth. With an increase in distance the trade flows decrease, as expected. The innovation expenditures of exporting countries have a positive and statistically significant effect on the progress indicator (i.e. bilateral intra-industrial trade flows between the sciencebased industries). In the case of the new EU members, where the share of multinationals in innovation expenditures is high, the bilateral trade flows between these industries decrease by about 3.64 times. Furthermore, the bilateral trade flows of the remaining, or less researchintensive, industries proxy the potential progress effect of imitation in our analysis. The size of and innovation within the science-based industries do not seem to promote the trade of imitated products. On the contrary, the effect is negative and significant, while in the case of new EU members the effect is positive and significant. The bilateral flows between less science-based industries increase by about 1.17 times in this group. All in all, the findings suggest that innovation-driven technological change and growth in the region is caused, to a large extent, by multinationals and foreign firms' affiliates operating in local industries. 


\section{References}

Afman, E., Maurel, M., 2009. Diplomatic Relations and Trade Reorientation in Transition Countries, in Recent Applications to the Gravity Models. Forthcoming in Cambridge University Press.

Anderson, J.E., 1979. A Theoretical Foundation for the Gravity Equation. American Economic Review 69(1), pp 106-116.

Barro, R., Sala-i-Martin, X., 1997. Technological Diffusion, Convergence, and Growth. Journal of Economic Growth 2(1), pp. 1-26.

Baysinger, B.D., Hoskisson, R.E., 1989. Diversification Strategy and R\&D Intensity in MultiProduct Firms. Academy of Management Journal 34, pp 205-214.

Bergstrand, J.H., 1990. The Heckscher-Ohlin-Samuelson Model, the Linder Hypothesis, and the Detyerminants of Bilateral Intra-Industry Trade. The Economic Journal 100, pp1216-1229.

Bernard, B., Jensen, B., 1999. Exceptional Exporter Performance: Cause, Effect, or Both? Journal of International Economics 47(1), pp. 1-25.

Bessen, J., Maskin, E., 2000. Sequential Innovation, Patents, and Imitation. MIT Working Paper 11/99, Cambridge.

Bleaney, M., Wakelin, K., 2002. Efficiency, Innovation and Exports. Oxford Bulletin of Economic and Statistics 64(1), pp. 3-16.

Bottazzi, L., Peri, G., 2003. Innovation and Spillovers in Regions: Evidence from European Patent Data. European Economic Review 47, pp 687-710.

Brouwer, E., Kleinknecht, A., 1999. Innovative Output, and a Firm's Propensity to Patent: an Exploration of CIS Micro Data. Research Policy 28, pp127-141.

Buxton, T., Mayer, D., Murfin, A., 1991. UK Trade Performance and R\&D. Economics of Innovation and New Technology 1(3), pp. 243-244.

Carstensen, K., Toubal, F., 2004. Foreign Direct Investment in Central and Eastern European Countries: a Dynamic Panel Analysis. Journal of Comparative Economics 32(1), pp. 3-22.

Clerides, S.K., Lach, S., Tybout, J.R., 1998. Is Learning by Exporting Important? MicroDynamic Evidence from Colombia, Mexico, and Morocco. Quarterly Journal of Economics 113(3), pp. 903-947.

Currie, D., Levine, P., Perlman J., Chui, M., 1999. Phases of Imitation and Innovation in a NorthSouth Endogenous Growth Model. Oxford Economic Papers, Oxford University Press 51(1), pp. 60-88.

Deadorff, A.V., 1984. Testing Trade Theories and Predicting Trade Flows. Handbook of International Economics, Volume 1, Amsterdam: North-Holland.

Deadorff, A.V., 1998. Determinants of Bilateral Trade: Does Gravity Work in a Neoclassical World. J.A. Frankel, ed. The Regionalization of the World Economy, The University of Chicago Press, Chicago, London.

Demekas, D.G., Horvath, B., Ribakova, E., Wu, Y., 2007. Foreign Direct Investment in European Transition Economies-The Role of Policies. Journal of Comparative Economics 35, pp. 369-386.

Devinney, T.M., 1993. How Well do Patents Measure New Product Activity? Economic Letters 41, pp. 447-450.

Disdier, A., Mayer, T., 2004. How Different is Eastern Europe? Structure and Determinants of Location Choices by French Firms in Eastern and Western Europe. Journal of Comparative Economics 32, pp. 280-296. 
Eaton, J., Kortum, S., 2002. Technology, Geography, and Trade. Econometrica 70(5), pp. 17411779 .

Ernst, H., 2001. Patent Applications and Subsequent Changes of Performance: Evidence from Time-Series Cross-Section Analyses on the Firm Level. Research Policy 30(2), pp. 105119.

Estrin, S., Hanousek, J., Kočenda, E., Svejnar, J., 2009. Effects of Privatization and Ownership in Transition Economies. Journal of Economic Literature 47(3), 699-728.

Evenett, S., Keller, W., 2002. On Theories Explaining the Success of the Gravity Equation. Journal of Political Economy 110(2), pp. 281-316.

Eurostat, 2004. Statistics in focus. Theme 9-5/2004.

Fagerberg, J., 1988. International Competitiveness. Economic Journal 98 (391), pp. 355-374.

Fagerberg, J., Srholec, M. and Knell, M., 2007. The The Competitiveness of Nations: Why Some

Countries Prosper While Others Fall Behind. World Development, 35(10), pp. 1595-1620.

Freeman, C., Soete, L., 1997. The Economics of Industrial Innovation. Pinter, London.

Freud, L., Weinhold, D., 2004. The Effect of the Internet on International Trade. Journal of International Economics 62(1), pp. 171-189.

Fung, C., Iizaka, H., Tong, S. (2004) Foreign Direct Investment in China: Policy, Trend and Impact. Global Economic Review, 33(2), pp. 99-130.

Gassebner, M., Keck, A., Teh, R., 2006. The Impact of Disasters on International Trade. Working paper ERSD-2006-04, World Trade Organization.

Glass, A., Saggi, K., 1998. International Technology Transfer and the Technology Gap. Journal of Development Economics 55, pp. 369-398.

Greenaway, D., Milner, C., 1986. The Economics of Intra-Industry Trade. Basil Blackwell.

Griliches, Z., 1998. R\&D and Productivity: The Econometric Evidence. The University of Chicago Press, Chicago.

Grossman, G.M., Helpman, E., 1990. Comparative Advantage and Long Run Growth. American Economic Review 80(4), pp. 796-815.

Grossman, G.M., Helpman, E., 1991. Innovation and Growth in the Global Economy. Cambridge, MA: MIT Press.

Gruber, H., Lloyd, P., 1975. Intra-Industry Trade. Macmillan.

Grupp, H., 1998. Foundation of the Economics of Innovation: Theory, Measurement, and Practice. Edwards Elgar Publishing, Inc., UK.

Grupp, H., Maital, S., 2000. Perceived Innovation of Israel's Largest Firms: an Empirical Study. Technovation 20, pp. 129-137.

Hagedoorn, J., Cloodt, M., 2003. Measuring Innovative Performance: Is there an Advantage in Using Multiple Indicators? Research Policy 32, pp. 1365-1379.

Helpman, E., 1981. International Trade in the Presence of Product Differentiation, Economies of Scale and Monopolistic Competition: A Chamberlin Heckscher-Ohlin Approach. Journal of International Economics 11, pp 305-340.

Helpman, E., 1987. Imperfect Competition and International Trade: Evidence From Fourteen Industrial Countries. Journal of the Japanese and International Economies 1(1), pp. 62-81.

Jaffe, A., Trajtenberg, M., 2002. Patent, Citations and Innovations. Cambridge, MA: MIT Press.

Jones, C., 1995. Models of R\&D and Endogenous Growth. Journal of Political Economy 103, pp.759-784.

Jones, C., Williams, C., 2000. Too Much of a Good Thing? The Economics of Investment in R\&D. Journal of Economic Growth 5, pp. 65-85.

Kočenda, E., 2001. Macroeconomic Convergence in Transition Countries. Journal of 
Comparative Economics 29(1), pp. 1-23.

Kočenda, E., Kutan, A.M., Yigit, T.M., 2006. Pilgrims to the Eurozone: How Far, How Fast? Economic Systems 30(4), pp. 311-327.

Kočenda, E, Kutan, A.M., Yigit, T.M., 2008. Fiscal Convergence in the European Union. NorthAmerican Journal of Economics and Finance 19(3), pp.319-330.

Kočenda, E., Valachy, J., 2006. Exchange rate volatility and regime change: Visegrad comparison. Journal of Comparative Economics 34(4), pp. 727-753.

Koukhartchouk, O., Maurel, M., 2004. Russia's Accession to the WTO: What Potential for Trade Increase. Journal of Comparative Economics 32(4), pp. 680-699.

Krugman, P., 1979. A Model of Innovation, Technology Transfer, and the World Distribution of Income. Journal of Political Economy 87(2), pp. 253-266.

Lachenmaier, S., Woessmann, L., 2004. Does Innovation Cause Exports? Evidence from Exogenous Innovation Impulses and Obstacles Using German Micro Data. CESifo Working papers, No. 1178.

Landesmann, M., Stehrer, R., 2006. Goodwin's Structural Economic Dynamics: Modeling Schumpeterian and Keynesian Insights. WIIW Working papers, No. 41.

Landesmann, M., Stehrer, R., 2007. Modelling International Economic Integration: Patterns of Catching-up and Foreign Direct Investment. Economia Politica 3, pp. 335-362.

Landesmann, M., Dobrinsky, R. 1995. Transforming Economies and European Integration. Edward Elgar.

Lansbury, M., Pain, N., Smidkova, K., 1996. Foreign Direct Investment in Central Europe Since 1990: An Econometric Study. National Institute Economic Review (May) 156, 104-114.

Leamer, E., Levinsohn, J., 1995. International Trade theory: The Evidence. Handbook of International Economics, V 3. G. Grossman and K. Rogoff, eds. Elsevier: Amsterdam.

Lefilleur, J., Maurel, M., 2010. Inter- and intra-industry linkages as a determinant of FDI in Central and Eastern Europe. Forthcoming in Economic Systems. Available at doi:10.1016/j.ecosys.2009.12.002

Linneman, H., 1966. An Economic Study of International Trade Flows. North-Holland Publishing Company, Amsterdam.

Morada-Gonzalez, L., Viaene, J-M., 2005. Trade Policy and Quality Leadership in Transition Economies. European Economic Review 49(2), pp.359-385.

Moudatsou, A., 2003. Foreign Direct Investment and Economic Growth in the European Union. Journal of Economic Integration 18(4), pp. 689-707.

OECD (1997) Revision of High Technology Sector and Product Classification. OECD, Paris.

Okimoto, D., Saxonhouse, G., 1987. Technology and the Future of the Economy. In K. Yamamura, K., Yasuba, Y. eds., The Political Economy of Japan 1, pp.385-419. The Domestic Transformation. Stanford: Stanford University Press.

Perez-Sebastian, F., 7. Public Support to Innovation and Imitation in a Non-Scale Growth Model. Journal of Economic Dynamics and Control 31(12), pp. 3791-3821.

Pianta, M., 2003. Innovation and Employment. In: J. Fagerberg, D. Mowery and R. Nelson (eds), Handbook of Innovation, Oxford University Press (forth).

Poyago-Theotoky, J., 1998. R\&D Competition in a Mixed Duopoly under Uncertainty and Easy Imitation. Journal of Comparative Economics 26, pp. 415-428.

Rivera-Batiz, L., Romer, P., 1991. Economic Integration and Endogenous Growth. Quarterly Journal of Economics 106(2), pp. 531-555.

Roland, G., 2001. Ten Years after Transition and Economics. IMF Staff Papers 48, Special Issue. Segerstrom, P.S., 1991. Innovation, Imitation, and Economic Growth. Journal of Political 
Economy 99(4), pp.807-827.

Segerstrom, P.S., 2000. The Long-run Growth Effect of R\&D Subsidies. Journal of Economic Growth 5(3), pp. 277-305.

Segerstrom, P.S., 2004. Intel Economics. Mimeo, Stockholm School of Economics.

Smith, V., Madsen, E., Dilling-Hansen, 2002. Do R\&D Investment Affect Export Performance? University of Copenhagen, Institute of Economics, Centre for Industrial Studies, Discussion Paper 09.

Welfens, P., 1999. Globalization of the Economy, Unemployment and Innovation: Structural Change, Schumpetrian Adjustment, and New Policy Challenges. Springer-Verlag Berlin Heidelberg New York.

Yao, S., Wei, K., 2007. Economic Growth in the Presence of FDI: The Perspective of Newly Industrializing Economies. Journal of Comparative Economics 35, pp. 211-234.

Young, A., 1991. Learning by Doing and the Dynamic Effects of International Trade. Quarterly Journal of Economic 106(2), pp. 369-405. 
Table 1: Innovating firms experienced obstacles for innovation: four industries (number of firms)

\begin{tabular}{|c|c|c|c|c|c|}
\hline Countries & Years & $\begin{array}{l}\text { Manufacture of } \\
\text { machinery and equipment } \\
\text { n.e.c., electrical and } \\
\text { optical equipment }\end{array}$ & $\begin{array}{l}\text { Coke, refined petroleum } \\
\text { products and nuclear fuel, } \\
\text { chemicals, chemical products } \\
\text { and man-made fibres }\end{array}$ & $\begin{array}{l}\text { Basic metals and } \\
\text { fabricated metal } \\
\text { products }\end{array}$ & $\begin{array}{l}\text { Transport } \\
\text { equipment }\end{array}$ \\
\hline 1 & 2 & 3 & 4 & 5 & 6 \\
\hline \multicolumn{6}{|c|}{ New EU members } \\
\hline \multirow{2}{*}{$\begin{array}{l}\text { Czech } \\
\text { republic }\end{array}$} & 2004 & 1509 & 225 & 1116 & 220 \\
\hline & 2006 & 1395 & 975 & 612 & 235 \\
\hline \multirow{2}{*}{ Hungary } & 2004 & 593 & 178 & 217 & 63 \\
\hline & 2006 & 442 & 568 & 415 & 119 \\
\hline \multirow{2}{*}{ Poland } & 2004 & 2730 & 742 & 1988 & 600 \\
\hline & 2006 & 2005 & 1855 & 1182 & 429 \\
\hline Slovakia & 2004 & 156 & 34 & 136 & 47 \\
\hline \multicolumn{6}{|c|}{ Old EU members } \\
\hline \multirow{3}{*}{ Austria } & 1996 & 658 & 60 & 474 & 36 \\
\hline & 2004 & 1511 & $\mathrm{n} / \mathrm{a}$ & 715 & $\mathrm{n} / \mathrm{a}$ \\
\hline & 2006 & 1164 & 703 & 725 & 103 \\
\hline \multirow{3}{*}{ Belgium } & 1996 & 413 & 132 & 390 & 62 \\
\hline & 2004 & 616 & 441 & 721 & 183 \\
\hline & 2006 & $\mathrm{n} / \mathrm{a}$ & $\mathrm{n} / \mathrm{a}$ & $\mathrm{n} / \mathrm{a}$ & $\mathrm{n} / \mathrm{a}$ \\
\hline \multirow{3}{*}{ Denmark } & 1996 & 1002 & 93 & 383 & 29 \\
\hline & 2004 & 399 & 62 & 197 & $\mathrm{n} / \mathrm{a}$ \\
\hline & 2006 & $\mathrm{n} / \mathrm{a}$ & $\mathrm{n} / \mathrm{a}$ & $\mathrm{n} / \mathrm{a}$ & $\mathrm{n} / \mathrm{a}$ \\
\hline \multirow{3}{*}{ Finland } & 1996 & 509 & 105 & 114 & 50 \\
\hline & 2004 & 569 & 40 & 334 & 65 \\
\hline & 2006 & $\mathrm{n} / \mathrm{a}$ & $\mathrm{n} / \mathrm{a}$ & $\mathrm{n} / \mathrm{a}$ & $\mathrm{n} / \mathrm{a}$ \\
\hline \multirow{3}{*}{ France } & 1996 & 5701 & 1781 & 2822 & 778 \\
\hline & 2004 & 5786 & 1405 & 4517 & 986 \\
\hline & 2006 & $\mathrm{n} / \mathrm{a}$ & 1453 & 755 & $\mathrm{n} / \mathrm{a}$ \\
\hline \multirow{3}{*}{ Germany } & 1996 & 8784 & 972 & 3365 & 371 \\
\hline & 2004 & 8456 & 1248 & 3970 & 1538 \\
\hline & 2006 & 10939 & 1830 & 3262 & 1152 \\
\hline \multirow{3}{*}{ Ireland } & 1996 & 340 & 94 & 98 & 72 \\
\hline & 2004 & $\mathrm{n} / \mathrm{a}$ & $\mathrm{n} / \mathrm{a}$ & $\mathrm{n} / \mathrm{a}$ & $\mathrm{n} / \mathrm{a}$ \\
\hline & 2006 & 403 & $\mathrm{n} / \mathrm{a}$ & 243 & 58 \\
\hline \multirow{3}{*}{ Italy } & 1996 & 1470 & 233 & 813 & 138 \\
\hline & 2004 & 12713 & 1214 & 9937 & 1246 \\
\hline & 2006 & $\mathrm{n} / \mathrm{a}$ & $\mathrm{n} / \mathrm{a}$ & $\mathrm{n} / \mathrm{a}$ & $\mathrm{n} / \mathrm{a}$ \\
\hline \multirow{3}{*}{ Luxembourg } & 1996 & 18 & 3 & 18 & $\mathrm{n} / \mathrm{a}$ \\
\hline & 2004 & 39 & 1 & 11 & $\mathrm{n} / \mathrm{a}$ \\
\hline & 2006 & 32 & 20 & 20 & $\mathrm{n} / \mathrm{a}$ \\
\hline \multirow{3}{*}{ Netherlands } & 1996 & 1462 & 381 & 557 & 269 \\
\hline & 2004 & 978 & 204 & 644 & 134 \\
\hline & 2006 & $\mathrm{n} / \mathrm{a}$ & $\mathrm{n} / \mathrm{a}$ & 346 & $\mathrm{n} / \mathrm{a}$ \\
\hline \multirow{3}{*}{ Portugal } & 1996 & 413 & 237 & 100 & 10 \\
\hline & 2004 & 1597 & 489 & 1498 & 351 \\
\hline & 2006 & 1077 & 1742 & 1609 & 336 \\
\hline
\end{tabular}




\begin{tabular}{|c|c|c|c|c|c|}
\hline 1 & 2 & 3 & 4 & 5 & 6 \\
\hline \multirow{3}{*}{ Spain } & 1996 & $\mathrm{n} / \mathrm{a}$ & $\mathrm{n} / \mathrm{a}$ & $\mathrm{n} / \mathrm{a}$ & $\mathrm{n} / \mathrm{a}$ \\
\hline & 2004 & 5274 & 1917 & 7162 & 1528 \\
\hline & 2006 & 5310 & 6553 & 5494 & 1143 \\
\hline \multirow{3}{*}{ Sweden } & 1996 & 1294 & 121 & 589 & 192 \\
\hline & 2004 & 955 & 180 & 961 & 289 \\
\hline & 2006 & $\mathrm{n} / \mathrm{a}$ & $\mathrm{n} / \mathrm{a}$ & $\mathrm{n} / \mathrm{a}$ & $\mathrm{n} / \mathrm{a}$ \\
\hline \multirow{3}{*}{$\begin{array}{l}\text { United } \\
\text { Kingdom }\end{array}$} & 1996 & 5522 & 1646 & 2608 & 555 \\
\hline & 2004 & 3097 & 518 & 2136 & 467 \\
\hline & 2006 & $\mathrm{n} / \mathrm{a}$ & $\mathrm{n} / \mathrm{a}$ & $\mathrm{n} / \mathrm{a}$ & $\mathrm{n} / \mathrm{a}$ \\
\hline
\end{tabular}

Note: Sign " $n / a$ " denotes that data are not available

Source: Eurostat (2004, 2006), Community Innovation Surveys

Table 2: Gross research and development expenditure (GERD) in selected countries

\begin{tabular}{|c|c|c|c|c|c|c|c|}
\hline $\begin{array}{l}R \& D \text { (EUR per } \\
\text { inhabitant) }\end{array}$ & $\begin{array}{c}\text { Czech } \\
\text { Republic }\end{array}$ & Hungary & Poland & $\begin{array}{c}\text { Slovak } \\
\text { Republic }\end{array}$ & $\begin{array}{l}\text { EU } 16 \\
(\mathrm{~min})\end{array}$ & $\begin{array}{c}\text { EU } 16 \\
\text { (average) }\end{array}$ & $\begin{array}{l}\text { EU } 16 \\
(\max )\end{array}$ \\
\hline 1996 & 45.70 & 22.40 & 20.90 & 28.30 & 52.90 & 345.59 & 515.40 \\
\hline 2001 & 81.00 & 53.70 & 34.60 & 27.80 & 77.90 & 529.57 & 1179.80 \\
\hline 2006 & 171.80 & 89.40 & 39.60 & 40.20 & 109.90 & 719.41 & 1328.60 \\
\hline $\begin{array}{l}\text { GERD by sources, } \\
2006 \text { (\% of total by } \\
\text { sources): }\end{array}$ & $\begin{array}{c}\text { Czech } \\
\text { Republic }\end{array}$ & Hungary & Poland & $\begin{array}{c}\text { Slovak } \\
\text { Republic }\end{array}$ & $\begin{array}{c}\text { EU } 16 \\
(\min )\end{array}$ & $\begin{array}{c}\text { EU } 16 \\
\text { (average) }\end{array}$ & $\begin{array}{l}\text { EU } 16 \\
(\max )\end{array}$ \\
\hline Abroad & 3.10 & 11.30 & 7.00 & 9.10 & 3.80 & 9.67 & 18.40 \\
\hline $\begin{array}{r}\text { Business } \\
\text { enterprises }\end{array}$ & 56.90 & 43.30 & 33.10 & 35.00 & 40.40 & 52.98 & 68.10 \\
\hline Government & 39.00 & 44.80 & 57.50 & 55.60 & 25.10 & 35.11 & 48.30 \\
\hline $\begin{array}{r}\text { Higher education } \\
\text { and private-non- } \\
\text { profit sector }\end{array}$ & 1.00 & 0.60 & 2.40 & 0.30 & 0.40 & 2.28 & 5.90 \\
\hline $\begin{array}{l}\text { Expenditures by } \\
\text { business } \\
\text { enterprises, } 2006 \\
\text { (\% of total by } \\
\text { countries): }\end{array}$ & $\begin{array}{c}\text { Czech } \\
\text { Republic }\end{array}$ & Hungary & Poland & $\begin{array}{c}\text { Slovak } \\
\text { Republic }\end{array}$ & $\begin{array}{l}\text { EU } 16 \\
(\mathrm{~min})\end{array}$ & $\begin{array}{c}\text { EU } 16 \\
\text { (average) }\end{array}$ & $\begin{array}{l}\text { EU } 16 \\
(\max )\end{array}$ \\
\hline 1996 & 0.47 & 0.17 & 0.55 & 0.14 & 0.20 & 5.88 & 28.62 \\
\hline 2001 & 0.44 & 0.19 & 0.41 & 0.09 & 0.13 & 6.66 & 31.68 \\
\hline 2006 & 0.87 & 0.33 & 0.36 & 0.07 & 0.16 & 6.62 & 30.82 \\
\hline $\begin{array}{r}\text { Business enterprise } \\
R \& D \text { expenditure } \\
\text { financed from } \\
\text { abroad (\% of } R \& D \\
\text { expenditures of } \\
\text { enterprises)* }\end{array}$ & $\begin{array}{c}\text { Czech } \\
\text { Republic }\end{array}$ & Hungary & Poland & $\begin{array}{c}\text { Slovak } \\
\text { Republic }\end{array}$ & $\begin{array}{r}\text { EU } 14 \\
(\min )\end{array}$ & $\begin{array}{c}\text { EU } 14 \\
\text { (average) }\end{array}$ & $\begin{array}{l}\text { EU } 14 \\
(\max )\end{array}$ \\
\hline 2001-2005, average & 3.60 & 19.66 & 2.21 & 2.37 & 1.77 & 8.10 & 14.92 \\
\hline 2006 & 2.62 & 15.88 & 6.64 & 10.88 & 3.31 & 8.03 & 11.62 \\
\hline
\end{tabular}

Note: *) Austria and the UK are excluded from computations due to missing data

Source: OECD (2006), Science and Technology Indicators. 
Table 3: Selected innovation indicators

\begin{tabular}{|c|c|c|c|c|c|}
\hline & Czech Republic & Hungary & Poland & Slovakia & EU-average \\
\hline \multicolumn{6}{|c|}{ 1. Technology balance of payments: net payments (mln. current dollars) } \\
\hline 1999 & 270 & 288 & 539 & 47 & 486 \\
\hline 2001 & 213 & 440 & 618 & 35 & 793 \\
\hline 2006 & 308 & 770 & 1694 & 224 & -1550 \\
\hline \multicolumn{6}{|c|}{ 2. Share of countries in triadic patent families (\% of total by countries) } \\
\hline 1999 & 0.03 & 0.08 & 0.02 & 0.01 & 2.92 \\
\hline 2005 & 0.11 & 0.28 & 0.09 & 0.02 & 6.25 \\
\hline \multicolumn{6}{|c|}{ 2.1. Patent applications filed under the Patent Co-operation Treat (total number)* } \\
\hline 2005 & 120 & 180 & 104 & 36 & 2669 \\
\hline \multicolumn{6}{|c|}{ 2.2. Foreign co-inventors in patent applications (\% of total number of applications) } \\
\hline 2005 & 38.56 & 28.77 & 37.88 & 45.83 & 25.34 \\
\hline \multicolumn{6}{|c|}{ 3. Export market share in high technology industries (\%, of total exports)* } \\
\hline 1999 & 7.85 & 19.45 & 2.26 & 3.50 & 14.96 \\
\hline 2001 & 9.10 & 20.61 & 2.71 & 3.17 & 16.52 \\
\hline 2004 & 13.66 & 21.92 & 2.73 & 4.68 & 14.55 \\
\hline 2006 & 12.74 & 20.33 & 3.11 & 5.43 & 15.08 \\
\hline
\end{tabular}

Notes: *) applications at the international phase (EPO designations) are taken for 2005 at the aggregate level; According to OECD, high technology products are defined as the sum of the following products: aerospace, computers, office machinery, electronics, instruments, pharmaceuticals, electrical machinery, and armament. Source: OECD (2008), Science and Technology Indicators.

Table 4: The main estimation results (by Random Effect model)

\begin{tabular}{|c|c|c|c|c|c|}
\hline \multicolumn{3}{|c|}{ Dependent variables: } & $\log \left(T_{i j t}^{\text {innov }}\right)$ & $\log \left(T_{i j t}^{i m i t}\right)$ & $\log \left(F_{i j t}\right)$ \\
\hline \multicolumn{3}{|c|}{ Independent variables: } & Model 1 & Model 2 & Model 3 \\
\hline Constant term & $\mathrm{C}$ & $\alpha_{0}$ & $\begin{array}{c}21.58 \\
(1.33)^{* * *}\end{array}$ & $\begin{array}{c}4.07 \\
(0.43)^{* * *}\end{array}$ & $\begin{array}{c}17.49 \\
(1.66)^{* * *}\end{array}$ \\
\hline $\begin{array}{l}\text { Value added of the industry in } \\
\text { country } i \text { / Value added of the } \\
\text { industry in country } j\end{array}$ & $\log \left(Y_{i t} / Y_{j t}\right)$ & $\alpha_{1}$ & $\begin{array}{c}0.22 \\
(0.06)^{* *}\end{array}$ & $\begin{array}{c}-0.07 \\
(0.02)^{* * *}\end{array}$ & $\begin{array}{c}0.23 \\
(0.07)^{* * *}\end{array}$ \\
\hline $\begin{array}{l}\text { The number of industry's } \\
\text { employees of country } i \text { (exporter)/ } \\
\text { The number of industry's } \\
\text { employees of country } j \text { (importer) }\end{array}$ & $\log \left(E_{i t} / E_{j t}\right)$ & $\alpha_{2}$ & $\begin{array}{l}-0.09 \\
(0.09)\end{array}$ & $\begin{array}{c}-0.04 \\
(0.03)^{*}\end{array}$ & $\begin{array}{c}0.05 \\
(0.12)\end{array}$ \\
\hline $\begin{array}{l}\text { Distance between the capital cities } \\
\text { of countries } i \text { and } j\end{array}$ & $\log \left(K_{i j}\right)$ & $\alpha_{3}$ & $\begin{array}{c}-1.22 \\
(0.17)^{* * *}\end{array}$ & $\begin{array}{l}-0.03 \\
(0.05)\end{array}$ & $\begin{array}{c}-1.16 \\
(0.19)^{* * *}\end{array}$ \\
\hline $\begin{array}{l}\text { Innovation expenditure in country } i \\
/ \text { Innovation expenditure in country } \\
j \text { at time } t-1\end{array}$ & $\log \left(I_{i t-1} / I_{j t-1}\right)$ & $\alpha_{4}$ & $\begin{array}{c}1.06 \\
(0.47)^{* *}\end{array}$ & $\begin{array}{c}-0.39 \\
(0.21)^{* *}\end{array}$ & $\begin{array}{c}-4.01 \\
(0.77)^{* * *}\end{array}$ \\
\hline Dummy for new EU members & $D$ & $\alpha_{5}$ & $\begin{array}{c}-1.29 \\
(0.31)^{* * *}\end{array}$ & $\begin{array}{c}0.16 \\
(0.09)^{*}\end{array}$ & $\begin{array}{c}-2.01 \\
(0.35)^{* * *}\end{array}$ \\
\hline Number of observations & & & 463 & 477 & 743 \\
\hline R-squared & & & 0.25 & 0.20 & 0.21 \\
\hline
\end{tabular}

Huber-White heteroskedasticity-consistent standard errors: $* * * * *, *$ denote $1 \%, 5 \%$ and $10 \%$ significance level, respectively. 
Table 5: Inward activity of multinationals (\%, share in national total manufacturing)

\begin{tabular}{|c|c|c|c|c|c|c|c|c|c|}
\hline & \multicolumn{4}{|c|}{2001} & \multicolumn{4}{|c|}{2006} \\
\hline & & 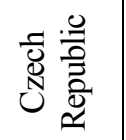 & 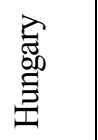 & $\begin{array}{l}\text { ్ㅕ } \\
\text { 응 }\end{array}$ & $\begin{array}{l}\frac{0}{a} \\
\frac{\pi}{0} \\
\frac{0}{n} \frac{2}{2}\end{array}$ & 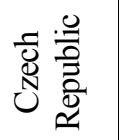 & 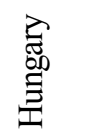 & 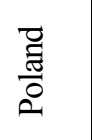 & 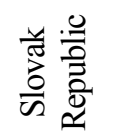 \\
\hline ISIC 3 & Variables & & & & & & & & \\
\hline \multirow{3}{*}{$\begin{array}{l}\text { Manufacturing } \\
\text { (total) }\end{array}$} & $\begin{array}{l}\text { Number of } \\
\text { establishments }\end{array}$ & 3.1 & 8.3 & 13.9 & $\mathrm{n} / \mathrm{a}$ & 4.3 & 1.9 & 16.9 & 10.2 \\
\hline & \begin{tabular}{|l|} 
Turnover \\
\end{tabular} & 43.3 & $\mathrm{n} / \mathrm{a}$ & 35.2 & $\mathrm{n} / \mathrm{a}$ & 55.9 & 61.9 & 45.5 & 70.5 \\
\hline & R\&D expenditures & 60.1 & $\mathrm{n} / \mathrm{a}$ & 6.6 & 33 & 71.6 & $\mathrm{n} / \mathrm{a}$ & 32 & 64.1 \\
\hline \multirow{3}{*}{$\begin{array}{l}\text { Chemical } \\
\text { products }\end{array}$} & $\begin{array}{l}\text { Number of } \\
\text { establishments }\end{array}$ & 4.7 & 18.1 & 19 & $\mathrm{n} / \mathrm{a}$ & 7.7 & 7.7 & 24.1 & 15.4 \\
\hline & \begin{tabular}{|l|} 
Turnover \\
\end{tabular} & 31 & 43.3 & 40.6 & $\mathrm{n} / \mathrm{a}$ & 67.1 & 47.8 & 47.5 & 55.4 \\
\hline & R\&D expenditures & 37.4 & $\mathrm{n} / \mathrm{a}$ & 1.4 & 38.3 & 89.6 & $\mathrm{n} / \mathrm{a}$ & $\mathrm{n} / \mathrm{a}$ & 90.7 \\
\hline \multirow{3}{*}{$\begin{array}{l}\text { Drugs and } \\
\text { medicines }\end{array}$} & $\begin{array}{l}\text { Number of } \\
\text { establishments }\end{array}$ & $\mathrm{n} / \mathrm{a}$ & $\mathrm{n} / \mathrm{a}$ & 25.9 & $\mathrm{n} / \mathrm{a}$ & $\mathrm{n} / \mathrm{a}$ & $\mathrm{n} / \mathrm{a}$ & 24.8 & $\mathrm{n} / \mathrm{a}$ \\
\hline & Turnover & $\mathrm{n} / \mathrm{a}$ & $\mathrm{n} / \mathrm{a}$ & 26.6 & $\mathrm{n} / \mathrm{a}$ & $\mathrm{n} / \mathrm{a}$ & $\mathrm{n} / \mathrm{a}$ & 58.2 & $\mathrm{n} / \mathrm{a}$ \\
\hline & R\&D expenditures & 41.5 & $\mathrm{n} / \mathrm{a}$ & $\mathrm{n} / \mathrm{a}$ & $\mathrm{n} / \mathrm{a}$ & 96.5 & $\mathrm{n} / \mathrm{a}$ & $\mathrm{n} / \mathrm{a}$ & $\mathrm{n} / \mathrm{a}$ \\
\hline \multirow{3}{*}{$\begin{array}{l}\text { Fabricated } \\
\text { metal products }\end{array}$} & $\begin{array}{l}\text { Number of } \\
\text { establishments }\end{array}$ & 3.3 & $\mathrm{n} / \mathrm{a}$ & 13.9 & $\mathrm{n} / \mathrm{a}$ & 5.6 & 1.0 & 18.3 & 9.2 \\
\hline & Turnover & 33.8 & $\mathrm{n} / \mathrm{a}$ & 22.9 & $\mathrm{n} / \mathrm{a}$ & 38.6 & 27.3 & 34.7 & 38.3 \\
\hline & R\&D expenditures & 10.8 & $\mathrm{n} / \mathrm{a}$ & 0.9 & $\mathrm{n} / \mathrm{a}$ & 33.8 & $\mathrm{n} / \mathrm{a}$ & 5.8 & $\mathrm{n} / \mathrm{a}$ \\
\hline \multirow{3}{*}{$\begin{array}{l}\text { Total } \\
\text { machinery and } \\
\text { equipment }\end{array}$} & $\begin{array}{l}\text { Number of } \\
\text { establishments }\end{array}$ & 2.4 & $\mathrm{n} / \mathrm{a}$ & 13.3 & $\mathrm{n} / \mathrm{a}$ & 3.8 & 2.8 & 17.1 & 13.7 \\
\hline & Turnover & 49.6 & 83.5 & 45.8 & $\mathrm{n} / \mathrm{a}$ & 63.9 & 81.1 & 55.1 & 77.6 \\
\hline & R\&D expenditures & 30.8 & $\mathrm{n} / \mathrm{a}$ & 10.4 & $\mathrm{n} / \mathrm{a}$ & 51.8 & $\mathrm{n} / \mathrm{a}$ & 15.1 & $\mathrm{n} / \mathrm{a}$ \\
\hline \multirow{3}{*}{$\begin{array}{l}\text { Office, } \\
\text { accounting } \\
\text { and computing } \\
\text { machinery }\end{array}$} & $\begin{array}{l}\text { Number of } \\
\text { establishments }\end{array}$ & 5.5 & $\mathrm{n} / \mathrm{a}$ & 16 & $\mathrm{n} / \mathrm{a}$ & 5.2 & 4.4 & $\mathrm{n} / \mathrm{a}$ & 9.8 \\
\hline & Turnover & 93.9 & $\mathrm{n} / \mathrm{a}$ & 20.7 & $\mathrm{n} / \mathrm{a}$ & 95.9 & 35.3 & $\mathrm{n} / \mathrm{a}$ & 25.9 \\
\hline & R\&D expenditures & $\mathrm{n} / \mathrm{a}$ & $\mathrm{n} / \mathrm{a}$ & $\mathrm{n} / \mathrm{a}$ & $\mathrm{n} / \mathrm{a}$ & $\mathrm{n} / \mathrm{a}$ & $\mathrm{n} / \mathrm{a}$ & 29.4 & $\mathrm{n} / \mathrm{a}$ \\
\hline \multirow{3}{*}{$\begin{array}{l}\text { Electrical } \\
\text { machinery and } \\
\text { electronic } \\
\text { equipment }\end{array}$} & $\begin{array}{l}\text { Number of } \\
\text { establishments }\end{array}$ & 1.7 & $\mathrm{n} / \mathrm{a}$ & 20.1 & $\mathrm{n} / \mathrm{a}$ & 2.7 & 5.0 & 25.1 & 16.3 \\
\hline & Turnover & 62.1 & $\mathrm{n} / \mathrm{a}$ & 65.7 & $\mathrm{n} / \mathrm{a}$ & 70.5 & 94.1 & 68.7 & 86.8 \\
\hline & R\&D expenditures & 35 & $\mathrm{n} / \mathrm{a}$ & 19.8 & 55.7 & 60.5 & $\mathrm{n} / \mathrm{a}$ & $\mathrm{n} / \mathrm{a}$ & $\mathrm{n} / \mathrm{a}$ \\
\hline \multirow{3}{*}{$\begin{array}{l}\text { Transport } \\
\text { equipment }\end{array}$} & $\begin{array}{l}\text { Number of } \\
\text { establishments }\end{array}$ & 10.1 & 19.1 & 24.9 & $\mathrm{n} / \mathrm{a}$ & 22.5 & 11.0 & 30.7 & 28.5 \\
\hline & Turnover & 83.5 & 91.7 & 70.1 & $\mathrm{n} / \mathrm{a}$ & 88 & 93.9 & 77.2 & 92.8 \\
\hline & R\&D expenditures & 85.6 & $\mathrm{n} / \mathrm{a}$ & 6.3 & $\mathrm{n} / \mathrm{a}$ & 83.8 & $\mathrm{n} / \mathrm{a}$ & 52.4 & $\mathrm{n} / \mathrm{a}$ \\
\hline \multirow{3}{*}{$\begin{array}{l}\text { Aircraft and } \\
\text { spacecraft }\end{array}$} & $\begin{array}{l}\text { Number of } \\
\text { establishments }\end{array}$ & $\mathrm{n} / \mathrm{a}$ & $\mathrm{n} / \mathrm{a}$ & 31.6 & $\mathrm{n} / \mathrm{a}$ & $\mathrm{n} / \mathrm{a}$ & $\mathrm{n} / \mathrm{a}$ & 61.1 & $\mathrm{n} / \mathrm{a}$ \\
\hline & Turnover & $\mathrm{n} / \mathrm{a}$ & $\mathrm{n} / \mathrm{a}$ & 15 & $\mathrm{n} / \mathrm{a}$ & $\mathrm{n} / \mathrm{a}$ & $\mathrm{n} / \mathrm{a}$ & 50.7 & $\mathrm{n} / \mathrm{a}$ \\
\hline & R\&D expenditures & 7.6 & $\mathrm{n} / \mathrm{a}$ & 2.6 & $\mathrm{n} / \mathrm{a}$ & 4.2 & $\mathrm{n} / \mathrm{a}$ & $\mathrm{n} / \mathrm{a}$ & $\mathrm{n} / \mathrm{a}$ \\
\hline \multirow{3}{*}{$\begin{array}{l}\text { Total business } \\
\text { enterprise }\end{array}$} & $\begin{array}{l}\text { Number of } \\
\text { establishments }\end{array}$ & 4 & $\mathrm{n} / \mathrm{a}$ & 8.8 & $\mathrm{n} / \mathrm{a}$ & 5.4 & $\mathrm{n} / \mathrm{a}$ & 12.0 & $\mathrm{n} / \mathrm{a}$ \\
\hline & Turnover & 30.1 & $\mathrm{n} / \mathrm{a}$ & 25 & $\mathrm{n} / \mathrm{a}$ & 41 & $\mathrm{n} / \mathrm{a}$ & 34.3 & $\mathrm{n} / \mathrm{a}$ \\
\hline & R\&D expenditures & 45.3 & $\mathrm{n} / \mathrm{a}$ & 4.6 & 19 & 58.6 & $\mathrm{n} / \mathrm{a}$ & 30.1 & 30.2 \\
\hline
\end{tabular}

Note: Sign " $n / a$ " denotes that data are not available

Source: OECD (2006), Main Science and Technology Indicators. 
Table 6: FDI inflows to the research intensive manufacturing sectors

\begin{tabular}{|c|c|c|c|c|c|c|c|c|c|c|c|c|}
\hline & \multicolumn{3}{|c|}{ Czech Republic } & \multicolumn{3}{|c|}{ Hungary } & \multicolumn{3}{|c|}{ Poland } & \multicolumn{3}{|c|}{ Slovakia } \\
\hline & 2001 & 2006 & $\begin{array}{l}2001- \\
2006\end{array}$ & 2001 & 2006 & $\begin{array}{l}2001- \\
2006\end{array}$ & 2001 & 2006 & $\begin{array}{l}2001- \\
2006 \\
\end{array}$ & 2001 & 2006 & $\begin{array}{l}2001- \\
2006 \\
\end{array}$ \\
\hline All industries & 5645 & 5465 & 38332 & 3936 & 20027 & 40556 & 5712 & 19591 & 57303 & 1451 & 4700 & 16141 \\
\hline Manufacture (ISIC 3) & 1654 & 1696 & 8912 & 2098 & 1477 & 9527 & 1204 & 4680 & 16435 & 249 & 2029 & 5905 \\
\hline Chemical products: & 2.32 & 9.58 & 6.58 & 13.70 & -4.57 & 7.01 & 1.06 & 14.35 & 9.83 & 9.08 & 3.41 & 6.27 \\
\hline $\begin{array}{r}\text {-pharmaceuticals, } \\
\text { medicinal chemical } \\
\text { and botanical } \\
\text { products }\end{array}$ & 0.00 & 7.29 & 2.82 & 0.00 & 22.94 & 5.18 & 0.00 & 0.00 & 0.00 & 0.00 & 0.00 & 0.00 \\
\hline $\begin{array}{l}\text { Metal and fabricated } \\
\text { metal products: }\end{array}$ & 9.23 & 34.81 & 33.04 & 4.88 & -3.39 & 10.05 & 0.44 & 24.44 & 21.06 & 2.41 & 30.61 & 27.96 \\
\hline -metal products & 5.21 & 19.13 & 20.75 & 2.95 & 14.25 & 7.94 & 5.55 & 19.86 & 15.28 & -0.44 & 28.45 & 24.85 \\
\hline -mechanical products & 4.02 & 15.68 & 12.29 & 1.93 & -17.64 & 2.11 & -5.11 & 4.58 & 5.77 & 2.85 & 2.16 & 3.12 \\
\hline $\begin{array}{l}\text { Machinery and } \\
\text { equipment: }\end{array}$ & 14.65 & 8.18 & 2.78 & 12.14 & -16.10 & 9.98 & 24.21 & 6.53 & 5.64 & 4.89 & 12.88 & 5.89 \\
\hline $\begin{array}{r}\text {-office machinery and } \\
\text { computers }\end{array}$ & 0.00 & 11.70 & 3.30 & 4.02 & -2.21 & 0.06 & 4.48 & 0.50 & 0.93 & 0.05 & -0.07 & 0.05 \\
\hline $\begin{array}{r}\text {-radio, } \mathrm{TV}, \\
\text { communication } \\
\text { equipments }\end{array}$ & 14.65 & -3.52 & -0.52 & 8.11 & -13.90 & 9.92 & 19.73 & 6.03 & 4.71 & 4.84 & 12.96 & 5.83 \\
\hline $\begin{array}{r}\text {-medical, precision } \\
\text { and optical } \\
\text { instruments, watches } \\
\text { and clocks } \\
\end{array}$ & 0.00 & -0.76 & 0.42 & 0.00 & -1.32 & 0.56 & 0.00 & 0.00 & 0.00 & 0.00 & 0.24 & 0.22 \\
\hline Transport equipment: & 23.66 & 4.56 & 13.96 & 31.07 & 54.52 & 34.41 & 8.12 & 17.94 & 20.84 & 54.57 & 30.41 & 28.68 \\
\hline -motor vehicles & 17.08 & 3.66 & 12.65 & 31.02 & 53.69 & 33.82 & 4.58 & 12.85 & 19.10 & 54.55 & 30.35 & 28.75 \\
\hline $\begin{array}{r}\text {-other transport } \\
\text { equipments } \\
\end{array}$ & 6.59 & 0.90 & 1.31 & 0.04 & 0.83 & 0.59 & 3.54 & 5.09 & 1.75 & 0.02 & 0.06 & -0.07 \\
\hline $\begin{array}{r}\text {-manufacture of } \\
\text { aircraft and spacecraft }\end{array}$ & 0.00 & 1.44 & 0.39 & 0.00 & 0.51 & 0.14 & 0.00 & 0.00 & 0.00 & 0.00 & 0.00 & 0.00 \\
\hline $\begin{array}{l}\text { Research and } \\
\text { development }\end{array}$ & 0.88 & -0.04 & 0.26 & -0.27 & -0.04 & 0.09 & 0.19 & 0.12 & 0.14 & -0.03 & 0.00 & 0.10 \\
\hline $\begin{array}{l}\text { Total share of } \\
\text { research incentive } \\
\text { sectors in } \\
\text { manufacture, \% }\end{array}$ & 50.75 & 64.37 & 59.43 & 61.52 & 53.36 & 66.72 & 34.02 & 63.38 & 57.51 & 70.91 & 77.32 & 68.90 \\
\hline
\end{tabular}

Source: OECD: Science and Technology Indicators. 
Figure 1: Gross R\&D expenditures (EUR per one inhabitant)

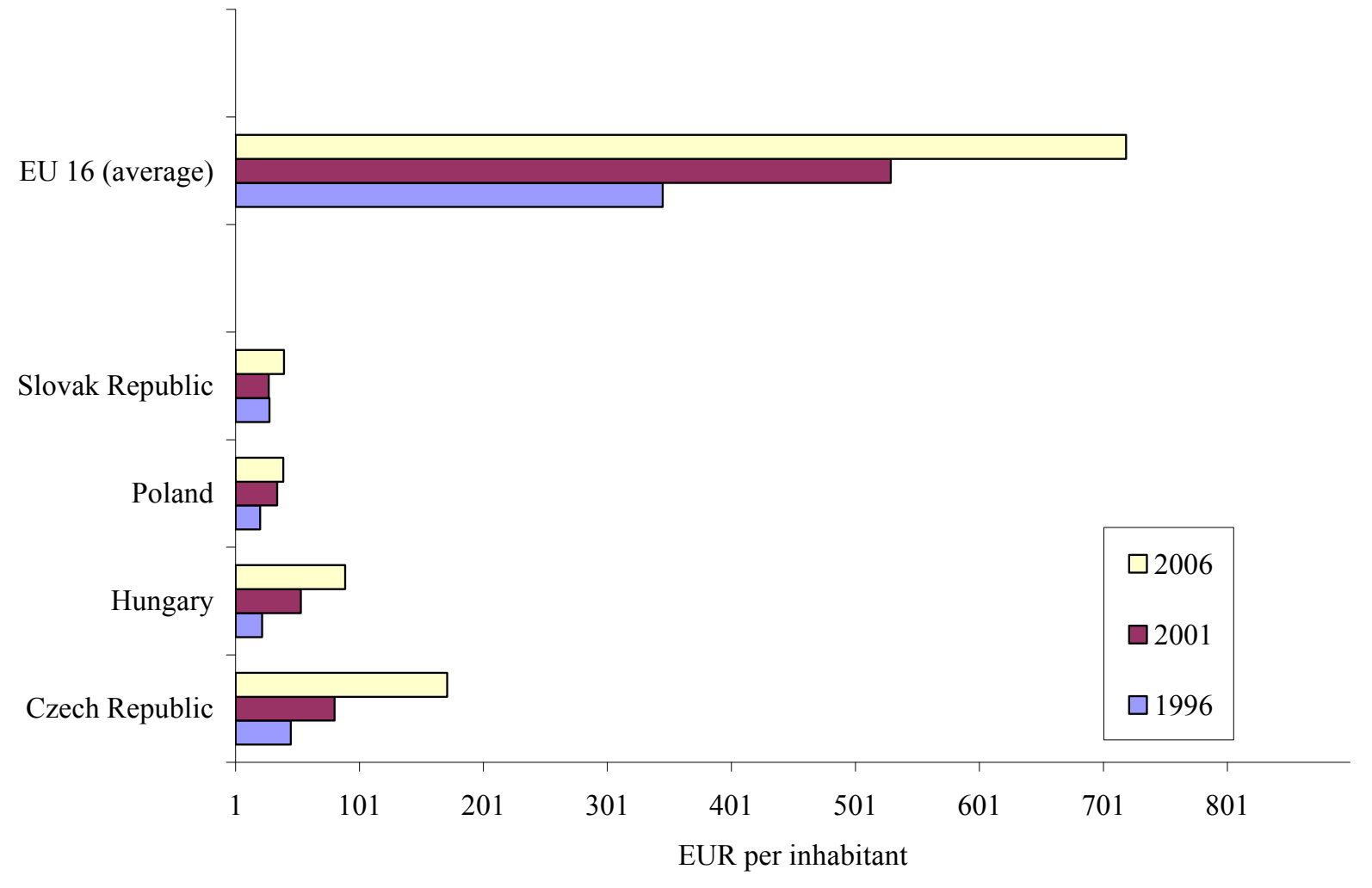

Figure 2: The size of GERD in 2006: by the sources of finance

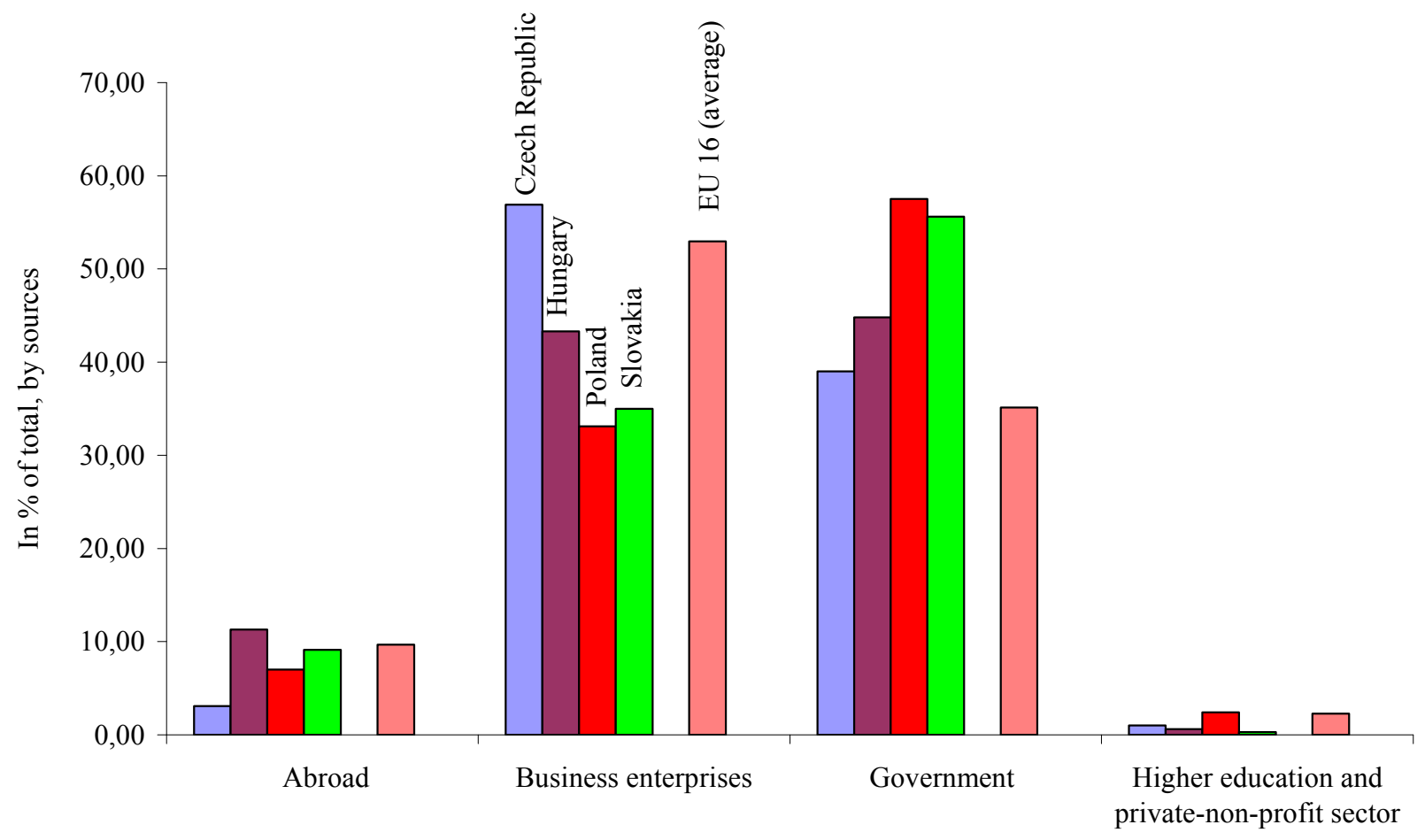


Figure 3: R\&D expenditure by business enterprises, \% of total by countries

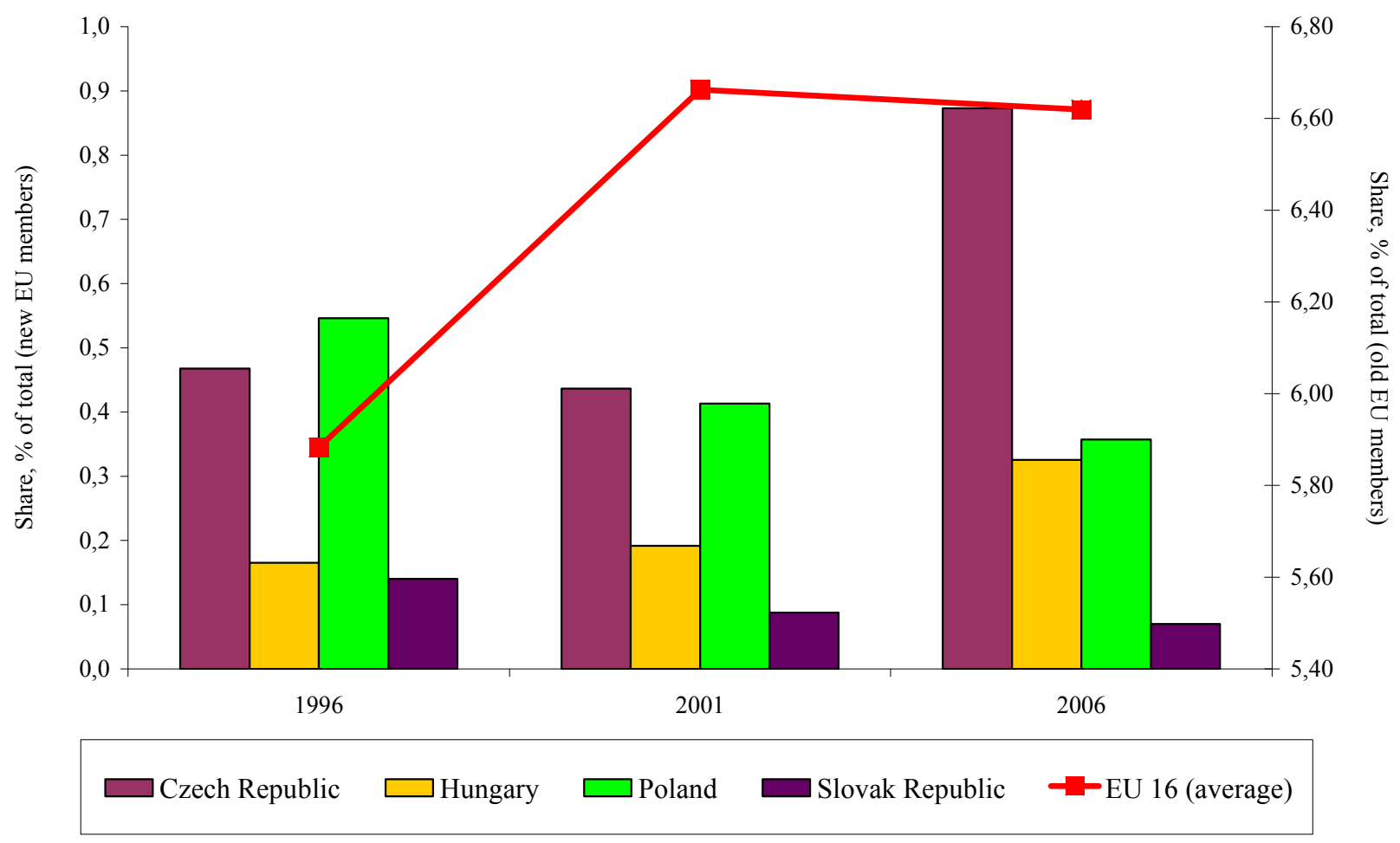

Figure 4: R\&D expenditure by business enterprises financed from abroad

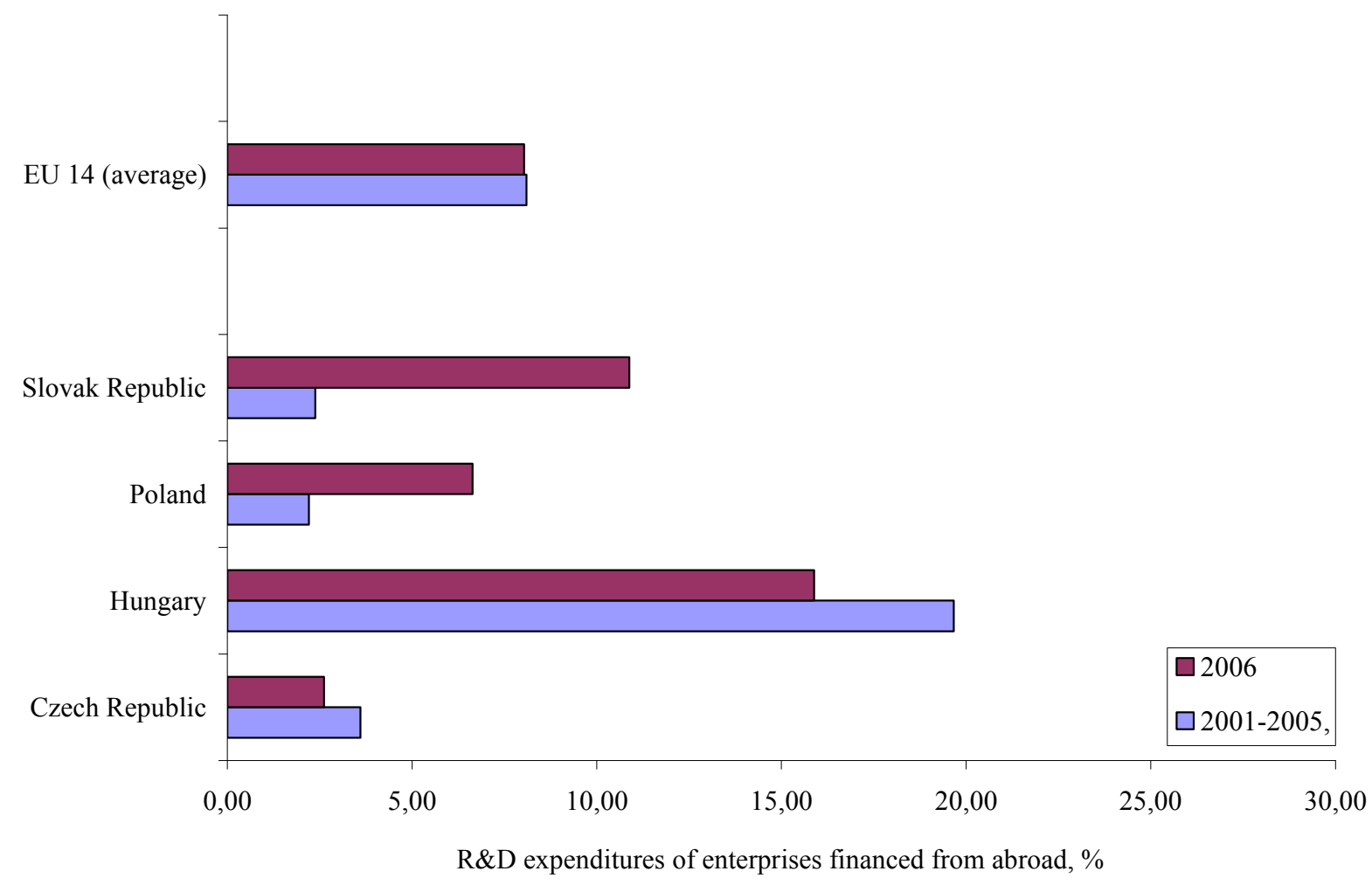




\section{Appendix}

Table A1: Estimation results (full results)

Regression 1: $\log \left(T_{i j t}^{i n n o v}\right)=\alpha_{0}+\alpha_{1} \log \left(Y_{i t} / Y_{j t}\right)+\alpha_{2} \log \left(E_{i t} / E_{j t}\right)+\alpha_{3} \log \left(D_{i s t}\right)+\alpha_{4} \log \left(I_{i t-1} / I_{j t-1}\right)+\alpha_{5} D+e_{i t}{ }^{l}$

\begin{tabular}{|c|c|c|c|c|c|}
\hline \multicolumn{2}{|l|}{ Variables } & & \multicolumn{3}{|c|}{ Coefficients obtained on } \\
\hline \multicolumn{3}{|l|}{ Dependent variable } & \multirow[b]{2}{*}{ OLS } & \multirow[b]{2}{*}{$\begin{array}{l}\text { Fixed effect } \\
\qquad(\mathrm{FE})\end{array}$} & \multirow[b]{2}{*}{$\begin{array}{l}\text { Random effect } \\
\text { (RE) }\end{array}$} \\
\hline $\begin{array}{l}\text { Intra-industrial trade flows from } \\
\text { country } i \text { to country } j \text { at time } t\end{array}$ & \multicolumn{2}{|c|}{$\log \left(T_{i j t}^{i n n o v}\right)$} & & & \\
\hline \multicolumn{3}{|l|}{ Independent variables: } & & & \\
\hline Constant term & $\mathrm{C}$ & $\alpha_{0}$ & $\begin{array}{l}25.32 \\
(2.50)^{* * *}\end{array}$ & $\begin{array}{l}32.81 \\
(21.54)^{*}\end{array}$ & $\begin{array}{l}21.58 \\
(1.33)^{* * *}\end{array}$ \\
\hline $\begin{array}{l}\text { Value added of the industry in country } i \text { / } \\
\text { Value added of the industry in country } j\end{array}$ & $\log \left(Y_{i t} / Y_{j t}\right)$ & $\alpha_{1}$ & $\begin{array}{l}0.24 \\
(0.05)^{* * *}\end{array}$ & $\begin{array}{l}0.62 \\
(0.24) * *\end{array}$ & $\begin{array}{l}0.22 \\
(0.06) * *\end{array}$ \\
\hline $\begin{array}{l}\text { The number of industry's employees of } \\
\text { country } i \text { / The number of industry's } \\
\text { employees of country } j\end{array}$ & $\log \left(E_{i t} / E_{j t}\right)$ & $\alpha_{2}$ & $\begin{array}{l}0.05 \\
(0.13) * *\end{array}$ & $\begin{array}{l}1.99 \\
(0.42)^{* * *}\end{array}$ & $\begin{array}{l}-0.09 \\
(0.09)\end{array}$ \\
\hline $\begin{array}{l}\text { Distance between the capital cities of } \\
\text { countries } i \text { and } j\end{array}$ & $\log \left(\right.$ Dist $\left._{i j}\right)$ & $\alpha_{3}$ & $\begin{array}{l}-1.27 \\
(0.25)^{* * *}\end{array}$ & $\begin{array}{l}-2.86 \\
(3.05)\end{array}$ & $\begin{array}{l}-1.22 \\
(0.17)^{* * *}\end{array}$ \\
\hline $\begin{array}{l}\text { Innovation expenditure in country } i / \\
\text { Innovation expenditure in country } j \text { at } \\
\text { time } t-1\end{array}$ & $\log \left(I_{i t-1} / I_{j t-1}\right)$ & $A_{4}$ & $\begin{array}{l}-2.08 \\
(1.65)^{*}\end{array}$ & $\begin{array}{l}0.90 \\
(0.50) * *\end{array}$ & $\begin{array}{l}1.06 \\
(0.47) * *\end{array}$ \\
\hline Dummy for new EU members & $D$ & $\alpha_{9}$ & $\begin{array}{l}-2.08 \\
(0.35) * * *\end{array}$ & dropped & $\begin{array}{l}-1.29 \\
(0.31)^{* * *}\end{array}$ \\
\hline Number of observations & & & 463 & 463 & 463 \\
\hline R-squared & & & 0.26 & 0.19 & 0.25 \\
\hline \multicolumn{6}{|c|}{ Hausman test: $\chi^{2}(4)=(b-B)^{\prime}\left[\left(V_{-} b-V_{-} B\right)^{\wedge}(-1)\right](b-B)$} \\
\hline Comparison with OLS & & & \# & 2.38 & 36.82 \\
\hline Between FE and RE & & & $\#$ & $\#$ & 38.17 \\
\hline
\end{tabular}




\begin{tabular}{|c|c|c|c|c|c|}
\hline \multicolumn{6}{|c|}{ Regression 2: $\log \left(T_{i j t}^{i m i t}\right)=\beta_{0}+\beta_{1} \log \left(Y_{i t} / Y_{j t}\right)+\beta_{2} \log \left(E_{i t} / E_{j t}\right)+\beta_{3} \log \left(\right.$ Dist $\left.t_{i j}\right)+\beta_{4} \log \left(I_{i t-l} / I_{j t-l}\right)+\beta_{5} D+e_{i t}^{2}$} \\
\hline \multicolumn{2}{|l|}{ Variables } & & \multicolumn{3}{|c|}{ Coefficients obtained on } \\
\hline \multicolumn{2}{|l|}{ Dependent variable } & & \multirow{2}{*}{ OLS } & \multirow{2}{*}{ FE } & \multirow{2}{*}{ RE } \\
\hline $\begin{array}{l}\text { Intra-industrial trade flows from country } \\
i \text { to country } j \text { at time } t\end{array}$ & $\log \left(T_{i j t}^{i m i t}\right)$ & & & & \\
\hline \multicolumn{2}{|l|}{ Independent variables: } & & & & \\
\hline Constant term & $\mathrm{C}$ & $B_{0}$ & $\begin{array}{l}7.06 \\
(0.87)^{* * *}\end{array}$ & $\begin{array}{l}-5.77 \\
(10.39)\end{array}$ & $\begin{array}{l}0.06 \\
(1.87)\end{array}$ \\
\hline $\begin{array}{l}\text { Value added of the industry in country } i \text { / } \\
\text { Value added of the industry in country } j\end{array}$ & $\log \left(Y_{i t} / Y_{j t}\right)$ & $B_{1}$ & $\begin{array}{l}0.01 \\
(0.03)\end{array}$ & $\begin{array}{l}-0.48 \\
(0.11)^{* * *}\end{array}$ & $\begin{array}{l}-0.18 \\
(0.04)^{* * *}\end{array}$ \\
\hline $\begin{array}{l}\text { The number of industry's employees of } \\
\text { country } i \text { / The number of industry's } \\
\text { employees of country } j\end{array}$ & $\log \left(E_{i t} / E_{j t}\right)$ & $B_{2}$ & $\begin{array}{l}0.15 \\
(0.08)^{* *}\end{array}$ & $\begin{array}{l}-0.39 \\
(0.19)^{* *}\end{array}$ & $\begin{array}{l}-0.14 \\
(0.07)^{* * *}\end{array}$ \\
\hline $\begin{array}{l}\text { Distance between the capital cities of } \\
\text { countries } i \text { and } j\end{array}$ & $\log \left(\right.$ Dist $\left._{i j}\right)$ & $B_{3}$ & $\begin{array}{l}-0.12 \\
(0.04)^{* * *}\end{array}$ & $\begin{array}{l}0.77 \\
(1.35)\end{array}$ & $\begin{array}{l}0.08 \\
(0.12)\end{array}$ \\
\hline $\begin{array}{l}\text { Innovation expenditure in country } i \text { at } \\
\text { time } t-1\end{array}$ & $\log \left(I_{i t-I}\right)$ & $B_{4}$ & $\begin{array}{l}-0.32 \\
(0.09)^{* * *}\end{array}$ & $\begin{array}{l}0.28 \\
(0.19)^{*}\end{array}$ & $\begin{array}{l}0.17 \\
(0.09)^{* *}\end{array}$ \\
\hline $\begin{array}{l}\text { Innovation expenditure in country } j \text { at } \\
\text { time } t-1\end{array}$ & $\log \left(I_{j t-1}\right)$ & $B_{5}$ & $\begin{array}{l}0.14 \\
(0.06)^{* * *}\end{array}$ & $\begin{array}{l}0.00 \\
(0.02)\end{array}$ & $\begin{array}{l}0.02 \\
(0.01)^{*}\end{array}$ \\
\hline Dummy for accession countries & $D$ & $B_{6}$ & $\begin{array}{l}-0.59 \\
(0.26)^{* *}\end{array}$ & dropped & $\begin{array}{l}0.79 \\
(0.32)^{* *}\end{array}$ \\
\hline \multicolumn{6}{|c|}{ Hausman test: $\chi^{2}(5)=(b-B)^{\prime}\left[\left(V_{-} \_-V \_B\right)^{\wedge}(-1)\right](b-B)$} \\
\hline Number of observations & & & 477 & 477 & 477 \\
\hline R-squared & & & 0.23 & 0.18 & 0.14 \\
\hline \multirow[t]{2}{*}{ Hausman test: } & \multicolumn{3}{|l|}{ with OLS } & 45.45 & 25.03 \\
\hline & \multicolumn{4}{|c|}{ between FE and RE } & 24.43 \\
\hline
\end{tabular}


Regression 3: $\log \left(F_{i j t}\right)=\gamma_{0}+\gamma_{1} \log \left(Y_{i t} / Y_{j t}\right)+\gamma_{2} \log \left(E_{i t} / E_{j t}\right)+\gamma_{3} \log \left(\operatorname{Dist}_{i j}\right)+\gamma_{4} \log \left(I_{i t-1}\right)+\gamma_{5} \log \left(I_{j t-1}\right)+\gamma_{6} D+e^{3}{ }_{i t}$

\begin{tabular}{|c|c|c|c|c|c|}
\hline Variables & & & & oefficients ol & d on \\
\hline \multicolumn{2}{|l|}{ Dependent variable } & & \multirow{2}{*}{ OLS } & \multirow{2}{*}{ FE } & \multirow{2}{*}{$\mathrm{RE}$} \\
\hline $\begin{array}{l}\text { FDI flows country } i \text { to country } j \text { at } \\
\text { time } t\end{array}$ & $\log \left(F_{i j t}\right)$ & & & & \\
\hline Constant term & $\mathrm{C}$ & $\alpha_{1}$ & $\begin{array}{l}-3.85 \\
(2.19)^{* *}\end{array}$ & $\begin{array}{l}-52.46 \\
(11.85)^{* * *}\end{array}$ & $\begin{array}{l}-5.45 \\
(2.67)^{* *}\end{array}$ \\
\hline Value added of the industry in country $i$ & $\log \left(Y_{i t}\right)$ & $\alpha_{2}$ & $\begin{array}{l}0.15 \\
(0.07)^{* *}\end{array}$ & $\begin{array}{l}1.04 \\
(0.39)^{* * *}\end{array}$ & $\begin{array}{l}0.33 \\
(0.10)^{* * *}\end{array}$ \\
\hline Value added of the industry in country $j$ & $\log \left(Y_{j t}\right)$ & $\alpha_{3}$ & $\begin{array}{l}-0.09 \\
(0.07)^{*}\end{array}$ & $\begin{array}{l}2.22 \\
(0.41)^{* * *}\end{array}$ & $\begin{array}{l}-0.05 \\
(0.08)\end{array}$ \\
\hline $\begin{array}{l}\text { The number of industry's employees of } \\
\text { country } i\end{array}$ & $\log \left(E_{i t}\right)$ & $\alpha_{4}$ & $\begin{array}{l}0.47 \\
(0.12)^{* * *}\end{array}$ & $\begin{array}{l}0.79 \\
(0.93)\end{array}$ & $\begin{array}{l}0.49 \\
(0.16)^{* * *}\end{array}$ \\
\hline $\begin{array}{l}\text { The number of industry's employees of } \\
\text { country } j\end{array}$ & $\log \left(E_{j t}\right)$ & $\alpha_{5}$ & $\begin{array}{l}0.10 \\
(0.11)\end{array}$ & $\begin{array}{l}-0.70 \\
(1.19)\end{array}$ & $\begin{array}{l}0.34 \\
(0.15)^{* * *}\end{array}$ \\
\hline $\begin{array}{l}\text { Distance between the capital cities of } \\
\text { countries } i \text { and } j\end{array}$ & $\log \left(K_{i j}\right)$ & $\alpha_{6}$ & $\begin{array}{l}-0.84 \\
(0.15)^{* * *}\end{array}$ & dropped & $\begin{array}{l}-0.75 \\
(0.18)^{* * *}\end{array}$ \\
\hline $\begin{array}{l}\text { Innovation expenditure in country } i \text { at } \\
\text { time } t-1\end{array}$ & $\log \left(I_{i t-1}\right)$ & $\alpha_{7}$ & $\begin{array}{l}0.00 \\
(0.09)\end{array}$ & $\begin{array}{l}0.05 \\
(0.17)\end{array}$ & $\begin{array}{l}-0.10 \\
(0.11)\end{array}$ \\
\hline $\begin{array}{l}\text { Innovation expenditure in country } j \text { at } \\
\text { time } t-1\end{array}$ & $\log \left(I_{j t-1}\right)$ & $\alpha_{8}$ & $\begin{array}{l}0.71 \\
(0.07) * * *\end{array}$ & $\begin{array}{l}-0.18 \\
(0.09) * *\end{array}$ & $\begin{array}{l}0.47 \\
(0.07) * * *\end{array}$ \\
\hline Dummy for accession countries & $D$ & $\alpha_{9}$ & $\begin{array}{l}-1.37 \\
(0.30)^{* * *}\end{array}$ & dropped & $\begin{array}{l}-1.68 \\
(0.41)^{* * *}\end{array}$ \\
\hline Number of observations & & & 743 & 743 & 743 \\
\hline R-squared & & & 0.41 & 0.16 & 0.39 \\
\hline \multicolumn{6}{|c|}{ Hausman test: $\chi^{2}(5)=(\mathrm{b}-\mathrm{B})^{\prime}\left[\left(\mathrm{V} \_\mathrm{b}-\mathrm{V} \_\mathrm{B}\right)^{\wedge}(-1)\right](\mathrm{b}-\mathrm{B})$} \\
\hline $\begin{array}{l}\text { Comparison of FE and RE with OLS: } \\
\text { Comparison between FE and RE: }\end{array}$ & & & & 268.63 & $\begin{array}{r}75.96 \\
138.48\end{array}$ \\
\hline
\end{tabular}

Notes: Huber-White heteroskedasticity-consistent standard errors: ***,**,* denote $1 \%, 5 \%$ and $10 \%$ significance level, respectively. The $\mathrm{H}_{0}$ hypothesis of "instruments are correlated with error terms" (based on NR2 $\chi 2$ ) is rejected in favour of valid instruments. 


\section{CESifo Working Paper Series}

for full list see www.cesifo-group.org/wp

(address: Poschingerstr. 5, 81679 Munich, Germany, office@cesifo.de)

2977 Johann K. Brunner and Susanne Pech, Optimum Taxation of Bequests in a Model with Initial Wealth, March 2010

2978 Guglielmo Maria Caporale and Nicola Spagnolo, Stock Market Integration between three CEECs, Russia and the UK, March 2010

2979 Florian Englmaier, Ales Filipi and Ravi Singh, Incentives, Reputation and the Allocation of Authority, March 2010

2980 Konstantinos Angelopoulos, George Economides and Apostolis Philippopoulos, What is the Best Environmental Policy? Taxes, Permits and Rules under Economic and Environmental Uncertainty, March 2010

2981 Frederick van der Ploeg, Rapacious Resource Depletion, Excessive Investment and Insecure Property Rights, March 2010

2982 Wolfram F. Richter and Christoph Braun, Efficient Subsidization of Human Capital Accumulation with Overlapping Generations and Endogenous Growth, March 2010

2983 Francesco Cinnirella, Marc Piopiunik and Joachim Winter, Why Does Height Matter for Educational Attainment? Evidence from German Pre-Teen Children, March 2010

2984 Bernard Van Praag, Well-being Inequality and Reference Groups - An Agenda for New Research, March 2010

2985 Francesca Barion, Raffaele Miniaci, Paolo M. Panteghini and Maria Laura Parisi, Profit Shifting by Debt Financing in Europe, March 2010

2986 Alexander Haupt and Magdalena Stadejek, The Choice of Environmental Policy Instruments: Energy Efficiency and Redistribution, March 2010

2987 John Komlos and Marek Brabec, The Trend of BMI Values among US Adults, March 2010

2988 Emanuele Massetti and Lea Nicita, The Optimal Climate Policy Portfolio when Knowledge Spills across Sectors, March 2010

2989 Helmut Rainer and Thomas Siedler, Family Location and Caregiving Patterns from an International Perspective, March 2010

2990 Toru Kikuchi and Ngo Van Long, A Simple Model of Service Offshoring with Time Zone Differences, March 2010

2991 Assaf Razin, Efraim Sadka and Benjarong Suwankiri, Migration and the Welfare State: Dynamic Political-Economy Theory, March 2010 
2992 Bård Harstad, Buy Coal! Deposit Markets Prevent Carbon Leakage, March 2010

2993 Axel Dreher, Stephan Klasen, James Raymond Vreeland and Eric Werker, The Costs of Favoritism: Is Politically-driven Aid less Effective?, March 2010

2994 Sven Neelsen and Thomas Stratmann, Effects of Prenatal and Early Life Malnutrition: Evidence from the Greek Famine, March 2010

2995 Claude Hillinger and Bernd Süssmuth, The Quantity Theory of Money: An Assessment of its Real Linchpin Prediction, March 2010

2996 Matthew M. Chingos and Martin R. West, Do More Effective Teachers Earn More Outside of the Classroom?, March 2010

2997 Laurence Jacquet and Dirk Van de gaer, A Comparison of Optimal Tax Policies when Compensation or Responsibility Matter, March 2010

2998 Valentina Bosetti, Carlo Carraro, Romain Duval and Massimo Tavoni, What Should we Expect from Innovation? A Model-Based Assessment of the Environmental and Mitigation Cost Implications of Climate-Related R\&D, March 2010

2999 Scott Alan Carson, Nineteenth Century Stature and Family Size: Binding Constraint or Productive Labor Force?, March 2010

3000 Jukka Pirttilä and Ilpo Suoniemi, Public Provision, Commodity Demand and Hours of Work: An Empirical Analysis, March 2010

3001 Bertrand Candelon and Franz C. Palm, Banking and Debt Crises in Europe: The Dangerous Liaisons?, March 2010

3002 Joan Costa-i-Font and Marin Gemmill-Toyama, Does Cost Sharing really Reduce Inappropriate Prescriptions?, March 2010

3003 Scott Barrett, Climate Treaties and Backstop Technologies, March 2010

3004 Hans Jarle Kind, Tore Nilssen and Lars Sørgard, Price Coordination in Two-Sided Markets: Competition in the TV Industry, March 2010

3005 Jay Pil Choi and Heiko Gerlach, Global Cartels, Leniency Programs and International Antitrust Cooperation, March 2010

3006 Aneta Hryckiewicz and Oskar Kowalewski, Why do Foreign Banks Withdraw from other Countries? A Panel Data Analysis, March 2010

3007 Eric A. Hanushek and Ludger Woessmann, Sample Selectivity and the Validity of International Student Achievement Tests in Economic Research, March 2010

3008 Dennis Novy, International Trade and Monopolistic Competition without CES: Estimating Translog Gravity, April 2010 
3009 Yin-Wong Cheung, Guonan Ma and Robert N. McCauley, Renminbising China's Foreign Assets, April 2010

3010 Michel Beine and Sara Salomone, Migration and Networks: Does Education Matter more than Gender?, April 2010

3011 Friedrich Schneider, Tilman Brück and Daniel Meierrieks, The Economics of Terrorism and Counter-Terrorism: A Survey (Part I), April 2010

3012 Friedrich Schneider, Tilman Brück and Daniel Meierrieks, The Economics of Terrorism and Counter-Terrorism: A Survey (Part II), April 2010

3013 Frederick van der Ploeg and Steven Poelhekke, The Pungent Smell of "Red Herrings": Subsoil Assets, Rents, Volatility and the Resource Curse, April 2010

3014 Vjollca Sadiraj, Jan Tuinstra and Frans van Winden, Identification of Voters with Interest Groups Improves the Electoral Chances of the Challenger, April 2010

3015 Guglielmo Maria Caporale, Davide Ciferri and Alessandro Girardi, Time-Varying Spot and Futures Oil Price Dynamics, April 2010

3016 Scott Alan Carson, Racial Differences in Body-Mass Indices for Men Imprisoned in $19^{\text {th }}$ Century US Prisons: A Multinomial Approach, April 2010

3017 Alessandro Fedele, Paolo M. Panteghini and Sergio Vergalli, Optimal Investment and Financial Strategies under Tax Rate Uncertainty, April 2010

3018 Laurence Jacquet, Take it or Leave it: Take-up, Optimal Transfer Programs, and Monitoring, April 2010

3019 Wilhelm Kohler and Jens Wrona, Offshoring Tasks, yet Creating Jobs?, April 2010

3020 Paul De Grauwe, Top-Down versus Bottom-Up Macroeconomics, April 2010

3021 Karl Ove Aarbu, Demand Patterns for Treatment Insurance in Norway, April 2010

3022 Toke S. Aidt and Jayasri Dutta, Fiscal Federalism and Electoral Accountability, April 2010

3023 Bahram Pesaran and M. Hashem Pesaran, Conditional Volatility and Correlations of Weekly Returns and the VaR Analysis of 2008 Stock Market Crash, April 2010

3024 Stefan Buehler and Dennis L. Gärtner, Making Sense of Non-Binding Retail-Price Recommendations, April 2010

3025 Leonid V. Azarnert, Immigration, Fertility, and Human Capital: A Model of Economic Decline of the West, April 2010

3026 Christian Bayer and Klaus Wälde, Matching and Saving in Continuous Time: Theory and 3026-A Matching and Saving in Continuous Time: Proofs, April 2010 
3027 Coen N. Teulings and Nick Zubanov, Is Economic Recovery a Myth? Robust Estimation of Impulse Responses, April 2010

3028 Clara Graziano and Annalisa Luporini, Optimal Delegation when the Large Shareholder has Multiple Tasks, April 2010

3029 Erik Snowberg and Justin Wolfers, Explaining the Favorite-Longshot Bias: Is it RiskLove or Misperceptions?, April 2010

3030 Doina Radulescu, The Effects of a Bonus Tax on Manager Compensation and Welfare, April 2010

3031 Helmut Lütkepohl, Forecasting Nonlinear Aggregates and Aggregates with Timevarying Weights, April 2010

3032 Silvia Rocha-Akis and Ronnie Schöb, Welfare Policy in the Presence of Unionised Labour and Internationally Mobile Firms, April 2010

3033 Steven Brakman, Robert Inklaar and Charles van Marrewijk, Structural Change in OECD Comparative Advantage, April 2010

3034 Dirk Schindler and Guttorm Schjelderup, Multinationals, Minority Ownership and TaxEfficient Financing Structures, April 2010

3035 Christian Lessmann and Gunther Markwardt, Decentralization and Foreign Aid Effectiveness: Do Aid Modality and Federal Design Matter in Poverty Alleviation?, April 2010

3036 Eva Deuchert and Conny Wunsch, Evaluating Nationwide Health Interventions when Standard Before-After Doesn't Work: Malawi's ITN Distribution Program, April 2010

3037 Eric A. Hanushek and Ludger Woessmann, The Economics of International Differences in Educational Achievement, April 2010

3038 Frederick van der Ploeg, Aggressive Oil Extraction and Precautionary Saving: Coping with Volatility, April 2010

3039 Ainura Uzagalieva, Evžen Kočenda and Antonio Menezes, Technological Imitation and Innovation in New European Union Markets, April 2010 